PNNL-17800

U.S. DEPARTMENT OF

(i.) ENERGY

Prepared for the U.S. Department of Energy

under Contract DE-AC05-76RL01830

\title{
Uranium Metal Analysis via Selective Dissolution
}

\author{
$\mathrm{CH}$ Delegard \\ SI Sinkov \\ AJ Schmidt \\ JW Chenault
}

September 2008 


\title{
DISCLAIMER
}

This report was prepared as an account of work sponsored by an agency of the United States Government. Neither the United States Government nor any agency thereof, nor Battelle Memorial Institute, nor any of their employees, makes any warranty, express or implied, or assumes any legal liability or responsibility for the accuracy, completeness, or usefulness of any information, apparatus, product, or process disclosed, or represents that its use would not infringe privately owned rights. Reference herein to any specific commercial product, process, or service by trade name, trademark, manufacturer, or otherwise does not necessarily constitute or imply its endorsement, recommendation, or favoring by the United States Government or any agency thereof, or Battelle Memorial Institute. The views and opinions of authors expressed herein do not necessarily state or reflect those of the United States Government or any agency thereof.

\author{
PACIFIC NORTHWEST NATIONAL LABORATORY \\ operated by \\ BATTELLE \\ for the \\ UNITED STATES DEPARTMENT OF ENERGY \\ under Contract DE-ACO5-76RL01830
}

Printed in the United States of America
Available to DOE and DOE contractors from the
Office of Scientific and Technical Information,
P.O. Box 62, Oak Ridge, TN 37831-0062;
ph: (865) 576-8401
fax: (865) 5765728
email: reports@adonis.osti.gov

\author{
Available to the public from the National Technical Information Service, \\ U.S. Department of Commerce, 5285 Port Royal Rd., Springfield, VA 22161 \\ ph: (800) 553-6847 \\ fax: (703) 605-6900 \\ email: orders@nits.fedworld.gov \\ online ordering: http://www.ntis.gov/ordering.htm
}




\section{Uranium Metal Analysis via Selective Dissolution}

CH Delegard

SI Sinkov

AJ Schmidt

JW Chenault

September 2008

Prepared for

the U.S. Department of Energy

under Contract DE-AC05-76RL01830

Pacific Northwest National Laboratory

Richland, Washington 99352 


\section{Summary}

Uranium metal, which is present in sludge held in the Hanford Site K West Basin, can create hazardous hydrogen atmospheres during sludge handling, immobilization, or subsequent transport and storage operations by its oxidation/corrosion in water. A thorough knowledge of the uranium metal concentration in sludge therefore is essential to successful sludge management and waste process design.

The goal of this work was to establish a rapid routine analytical method to determine uranium metal concentrations as low as $0.03 \mathrm{wt} \%$ in sludge even in the presence of up to 1000 -fold higher total uranium concentrations (i.e., up to $30 \mathrm{wt} \%$ and more uranium) for samples to be taken during the upcoming sludge characterization campaign and in future analyses for sludge handling and processing. This report describes the experiments and results obtained in developing the selective dissolution technique to determine uranium metal concentration in K Basin sludge. The work described in this report:

- provides a technical underpinning of the validity of the selective dissolution method, including the influence of various sludge components, in five test series using simulated and genuine sludges of widely varying composition

- establishes analytical parameters (concentrations, quantities, temperatures, and times) necessary to develop the selective dissolution sludge-digestion analytical procedure.

The uranium metal detection limit is estimated to be about $0.004 \mathrm{wt} \%$ based on the testing performed with actual sludge, thus meeting the goal detection limit of $0.03 \mathrm{wt} \%$. The detection limit largely is established by the trace residual uranium carryover that exists in the leached and rinsed sludge. In the final series of method validation tests using actual $\mathrm{K}$ Basin sludge, spiked with uranium metal at concentrations ranging from 0.025 to $1.29 \mathrm{wt} \%$, uranium metal recoveries averaged $99.4 \%$ with a standard deviation of $3.3 \%$.

Based on the favorable testing results, an analytical method has been developed, extensively reviewed, and approved for routine use under the Pacific Northwest National Laboratory Analytical Support Operations Quality Assurance Plan, and this is compliant with the Hanford Analytical Services Quality Assurance Requirements Document, HASQARD. 



\section{Acronyms}

$\begin{array}{ll}\text { BDL } & \text { below detection limit } \\ \text { HASQARD } & \text { Hanford Analytical Services Quality Assurance Requirements Document } \\ \text { ICP } & \text { inductively coupled plasma } \\ \text { IXM } & \text { inorganic ion exchange material } \\ \text { KPA } & \text { kinetic phosphorescence analysis } \\ \text { MWD } & \text { megawatt day } \\ \text { MTU } & \text { metric ton of uranium } \\ \text { NLOP } & \text { North Load-Out Pit } \\ \text { NR } & \text { not reported } \\ \text { OIER } & \text { organic ion exchange resin } \\ \text { PNNL } & \text { Pacific Northwest National Laboratory } \\ \text { PVT } & \text { pressure-volume-temperature measurements (gas) } \\ \text { QAPjP } & \text { Quality Assurance Project Plan } \\ \text { STP } & \text { Sludge Treatment Project } \\ \text { WIPP } & \text { Waste Isolation Pilot Plant } \\ \text { XRD } & \text { X-ray diffraction }\end{array}$





\section{Contents}

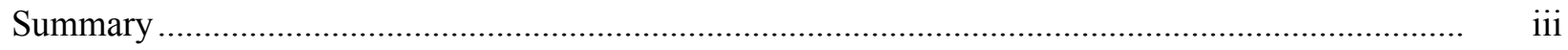

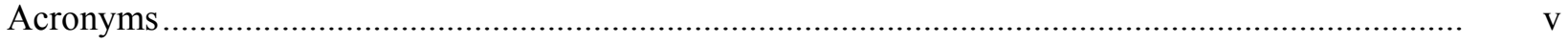

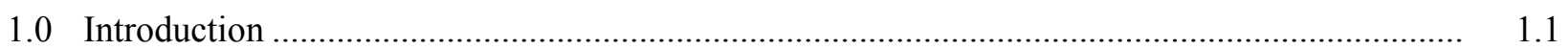

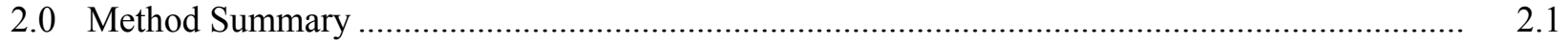

3.0 Technical Challenges Identified for Implementing the Selective Dissolution Approach........... 3.1

3.1 Dissolution of Uranium, Iron, and Aluminum Phases in Phosphoric Acid ......................... 3.1

3.2 Ion Exchange Behavior of K Basin Sludge Solids ......................................................... 3.2

3.3 Uranium Metal Dissolution in Nitric Acid .................................................................. 3.4

4.0 Experiments for Uranium Metal Dissolution Rate and Analysis of Uranium Metal Concentration in Simulated Sludge ............................................................................. 4.1

5.0 Results for Uranium Metal Dissolution Rate and Analysis in Simulated Sludge..................... 5.1

6.0 Experiments for Uranium Metal Analysis in K Basin Sludge ............................................... 6.1

7.0 Results for Uranium Metal Analysis in K Basin Sludge ..................................................... 7.1

8.0 Uranium Metal Concentrations in Sludge Compared with Analysis Targets............................ 8.1

9.0 Key Findings from Selective Dissolution Validation Testing .............................................. 9.1

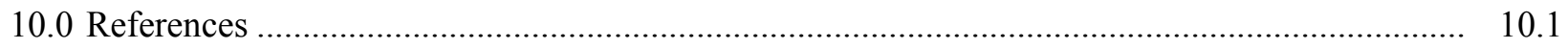




\section{Figures}

2.1. Block Flow Diagram for Selective Dissolution Analysis of Uranium Metal in Sludge ............. 2.2

3.1. Distribution Coefficients, $\mathrm{K}_{\mathrm{d}} \mathrm{s}$, for Various Metals onto Mordenite as Functions of $\mathrm{pH}$............ 3.3

3.2. Dependence of Uranium Metal Dissolution Rate on Total Nitrate Concentration at Boiling ..... 3.5

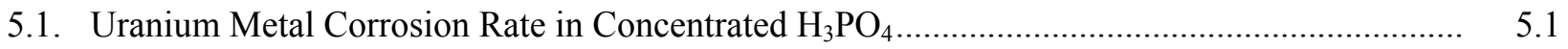

5.2. Uranium Metal Analysis Recoveries in Simulated Sludge ......................................................... 5.3

7.1. Absorbance Spectra of Solutions Produced by $\mathrm{Na}_{2} \mathrm{SO}_{4} / \mathrm{H}_{3} \mathrm{PO}_{4}$ Digestion of Blow Sand and

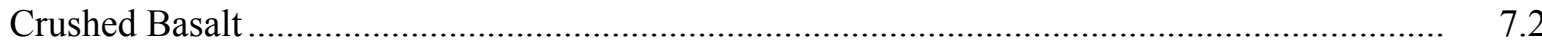

7.2. Spectra of Solutions Produced by $\mathrm{Na}_{2} \mathrm{SO}_{4} / \mathrm{H}_{3} \mathrm{PO}_{4}$ Digestion of Sludge Samples FE-5 and

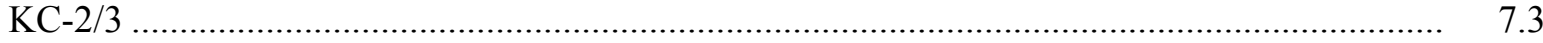

7.3. Uranium Metal Analysis Recoveries in Spiked and Unspiked K Basin Sludge ........................ 7.6

\section{Tables}

4.1. Composition of Simulated Sludge .................................................................................

4.2. Compositions of Test Items Prepared with Simulant Sludge, Uranium Metal, and IXM........... 4.2

5.1. Uranium Concentrations in 0.5 M Nitric Acid Rinses and in 10-M Nitric Acid Digestions for Simulated Sludge ...................................................................................................... 5.2

5.2. Uranium Metal Analysis Results in U-Metal Spiked and Unspiked K Basin Sludge Simulant .. $\quad 5.2$

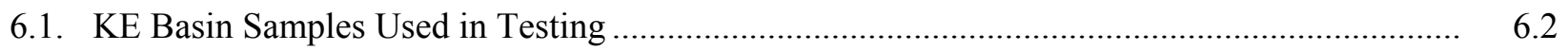

6.2. Chemical and Radiochemical Compositions of Sludge Used in Selective Dissolution Tests ..... 6.3

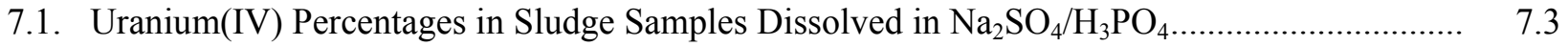

7.2. Uranium Concentrations in 0.5-M Nitric Acid Rinses and in 10-M Nitric Acid Digestions...... $\quad 7.4$

7.3. Uranium Metal Analysis Results in Uranium Metal Unspiked and Spiked K Basin Sludge ...... $\quad 7.5$

8.1. Uranium Metal Concentrations in Sludge and Considerations for Measurement Detection Limit 


\subsection{Introduction}

Uranium metal, which is present in sludge held in the Hanford Site K West Basin, can create hazardous hydrogen atmospheres during sludge handling, immobilization, or subsequent transport and storage operations by its oxidation/corrosion in water. A thorough knowledge of the uranium metal concentration in sludge therefore is essential to successful sludge management and waste process design.

The goal of this work was to establish a rapid routine analytical method to determine uranium metal concentrations as low as $0.03 \mathrm{wt} \%$ in sludge even in the presence of up to 1000 -fold higher total uranium concentrations (i.e., up to $30 \mathrm{wt} \%$ and more uranium) for samples to be taken during the upcoming sludge characterization campaign and in future analyses for sludge handling and processing. This report describes the experiments and results obtained in developing the selective dissolution technique to determine uranium metal concentration in $\mathrm{K}$ Basin sludge. The work described in this report:

- provides a technical underpinning of the validity of the selective dissolution method, including the influence of various sludge components, in five test series using simulated and genuine sludges of widely varying composition

- establishes analytical parameters (concentrations, quantities, temperatures, and times) necessary to develop the selective dissolution sludge digestion analytical procedure.

In previous sludge characterization efforts, uranium metal concentrations in K Basin sludge have been determined by the research method of gas-generation testing and, with much less sensitivity, a calorimetric method. In the calorimetric method, the heat evolved in the reaction of sludge with nitric acid is measured. Contributions to heat evolution include dilution of the acid by the water contained in the sludge, the dissolution of uranium oxides and aluminum and iron hydroxides, and the dissolution of uranium metal. The calorimetric technique is successful only if the concentrations of uranium metal are high ( $\sim 10 \mathrm{wt} \%$ or more), and good estimates are available of water, iron, aluminum, and total uranium concentrations.

In the gas-generation technique, the reaction of uranium metal with water is monitored by the evolution of the hydrogen gas reaction product and the accompanying release of fission product (krypton and xenon) gases. The total gas quantities and individual gas concentrations are determined by gas pressure-volumetemperature (PVT) measurements and by mass spectrometric analyses of gas compositions. The amounts of uranium metal are determined by chemical (hydrogen) and burn-up (krypton and xenon) correlations. Uranium metal concentrations as low as $0.005 \mathrm{wt} \%$ in settled sludge have been determined by measuring the amount of released xenon fission product gas (Bryan et al. 2004). Determining uranium metal concentration by hydrogen gas evolution is less reliable at low levels because it is complicated by the suspected disappearance of hydrogen by its reaction with oxidized uranium or iron compounds or by its creation by other means (corrosion of other metals such as aluminum and by radiolysis).

The gas-generation testing to determine uranium metal concentrations is performed in sealed vessels held thermostatically at 80 to $95^{\circ} \mathrm{C}$ for several thousand hours (up to 4 months). To measure uranium metal concentrations by fission-product gas release requires knowledge or assumptions of the parent fuel 
burnup. With multiple gas samples, knowledge of uranium metal particle size also can be obtained based on the reaction kinetics. In contrast, with selective dissolution, the uranium metal concentrations in sludge can be determined more quickly (within 1 to 2 weeks), but no information on uranium metal particle-size distribution in the sample is acquired. However, some information on uranium metal particle size can be obtained by sieving the sample and performing selective dissolution on the size-fractionated sub-samples.

Laboratory tests of selective dissolution were conducted from December 2007 to June 2008 using a simulated sludge and several types of genuine sludge. In both test types, known quantities of submillimeter-diameter uranium metal beads were added. The simulated sludge tests were performed with a comprehensive chemical surrogate that included iron and aluminum hydroxides, organic and inorganic ion exchange media of the same types used at the K Basins, Hanford blow sand, and uranium dioxide prepared by corroding uranium metal in water. Spiked uranium metal concentrations ranged from 0.03 to $0.4 \mathrm{wt} \%$ with respect to total wet settled sludge. Blank tests (without $\mathrm{U}$ metal) also were conducted. Uranium metal recoveries of 75 to $119 \%$ were achieved. The analytical background was about $0.01 \mathrm{wt} \%$ uranium metal as determined from the blank tests.

Testing with four types of actual sludge spiked with 0.006 to $0.026 \mathrm{wt} \%$ uranium metal beads (with respect to settled sludge) achieved recoveries ranging from 106 to 179\%. The high recoveries are at least partly due to the high relative contributions of the analytical background uranium compared with the small amounts of added uranium metal used in these tests. The analytical background was about $0.004 \mathrm{wt} \%$ as determined by blank tests.

Further tests were conducted with one of the four K Basin sludge types using $0.025-$ to $1.29-\mathrm{wt} \%$ added uranium metal as well as two blank tests. The average uranium metal recovery was $99.4 \mathrm{wt} \%$ with a standard deviation of $3.3 \mathrm{wt} \%$ with the blank tests again showing $0.004 \mathrm{wt} \%$ analytical background.

Because the origin of the uranium in the analytical background cannot distinguish between oxidized uranium and uranium metal, the analytical background is interpreted as the threshold below which uranium metal may be present in the sludge. It is noted that all chemical or radiochemical analyses experience this same phenomenon in that the lower analytical limit of the analyte in question, if reached for any sample, constitutes an estimate of the analyte's highest concentration.

The uranium metal detection limit is estimated to be about $0.004 \mathrm{wt} \%$ based on the testing performed with actual sludge, thus meeting the goal detection limit of $0.03 \mathrm{wt} \%$. In the final series of method validation tests using actual $\mathrm{K}$ Basin sludge, spiked with uranium metal at concentrations ranging from 0.025 to $1.29 \mathrm{wt} \%$, uranium metal recoveries averaged $99.4 \%$ with a standard deviation of $3.3 \%$. The detection limit largely is established by the trace residual uranium carryover that exists in the leached and rinsed sludge. The potential contamination of selective dissolutions in the hot cell environment, where work with K Basin sludge, N Reactor fuel, and other uranium-rich materials has been conducted over prior decades, also can contribute to an increase in the detection limit if strict measures to maintain sample purity are not observed. 
Based on the favorable testing results, an analytical digestion method has been developed, extensively reviewed, and approved for use under the Pacific Northwest National Laboratory (PNNL) Analytical Support Operations Quality Assurance Plan (i.e., compliant with the Hanford Analytical Services Quality Assurance Requirements Document, HASQARD; DOE 2007) for routine analytical use in PNNL's Radiochemical Processing Laboratory. The procedure is "Sample Preparation for Determination of Uranium Metal Concentrations in Sludge," RPG-CMC-107.

A technical data package supporting this work is maintained in the PNNL project records and has been provided to CH2M Hill Plateau Remediation Company (CHPRC): STP Records and STP Engineering (JP Sloughter, STP/BTR). The technical data package contains the approved PNNL Technical Procedure, "Sample Preparation for Determination of Uranium Metal Concentrations in Sludge," RPG-CMC-107, Rev 0; completed test instructions; supporting calculations; and supporting analytical data.

This report was prepared in accordance with the Statement of Work under PNNL Project 53451 (Contract 27647, Release 242) and the Quality Assurance Project Plan (QAPjP 2007). 


\subsection{Method Summary}

The alternative technique of staged or selective dissolution of uranium oxides to determine the concentration of uranium metal in K Basin sludge has been tested with both simulated K Basin sludge and actual sludge containing known amounts of added uranium metal. The technique relies on the relatively rapid dissolution of oxidized uranium compounds in concentrated phosphoric acid $\left(\mathrm{H}_{3} \mathrm{PO}_{4}\right.$; also containing $0.14 \mathrm{M} \mathrm{Na}_{2} \mathrm{SO}_{4}$ ) compared with the slow attack of uranium metal under the same conditions.

In selective dissolution, 3 to 5 grams of sludge is treated with $30 \mathrm{~mL}$ of $\mathrm{Na}_{2} \mathrm{SO}_{4}$-bearing $\mathrm{H}_{3} \mathrm{PO}_{4}$ for $\sim 2$ hours at $80^{\circ} \mathrm{C}$ to dissolve the oxidized uranium compounds. The work is performed in shielded cells (hot cells) for radiological safety. Some sludge compounds, such as the iron and aluminum (hydr)oxides [e.g., $\mathrm{FeOOH}, \mathrm{Al}(\mathrm{OH})_{3}$ ], also dissolve, but silica sand, zirconium cladding, organic and inorganic ion exchange media, and uranium metal do not dissolve under these conditions. A second contact with $10 \mathrm{~mL}$ of fresh $\mathrm{Na}_{2} \mathrm{SO}_{4}$-bearing $\mathrm{H}_{3} \mathrm{PO}_{4}$ is performed for 1 to 2 hours to improve dissolution and removal of the oxidized uranium compounds. Intermittent vortex mixing (about 4 times per hour) is used to improve the oxidized uranium phase dissolution. ${ }^{\text {(a) }}$ The $\mathrm{Na}_{2} \mathrm{SO}_{4} / \mathrm{H}_{3} \mathrm{PO}_{4}$ solution may be analyzed spectrophotometrically to determine the oxidation state distribution of the oxidized uranium compounds (Sinkov et al. 2008) or may be discarded.

The solid residue is washed quickly seven times by $10-\mathrm{mL}$ aliquots of cell-temperature $0.5 \mathrm{M}$ nitric acid $\left(\mathrm{HNO}_{3}\right)$ to rinse out the dissolved uranium compound solution. The first, third, fifth, and seventh contacts are performed with vortex mixing to improve rinsing and to wash down the vessel walls. The residual rinsed solid heel then is treated with $10 \mathrm{~mL}$ of $105^{\circ} \mathrm{C} 10 \mathrm{M} \mathrm{HNO}_{3}$ for about 2 hours to dissolve the uranium metal. The solutions from the last two $0.5-\mathrm{M} \mathrm{HNO}_{3}$ rinses may be analyzed for uranium concentrations to determine the thoroughness of the washing step. The solution from the $10-\mathrm{M} \mathrm{HNO}_{3}$ metal dissolution step with a contained sludge heel and vessel is weighed and the solution decanted and analyzed for uranium concentration to determine the amount of uranium metal contained in the sludge. The sludge heel is dried in the tare-weighed digestion vessel and vessel plus dried sludge heel weighed to determine the sludge heel weight and, by difference, the weight of $10-\mathrm{M} \mathrm{HNO}_{3}$ digestate. The $\mathrm{HNO}_{3}$ used in the rinse and metal dissolution steps is "Ultrex" grade prepared and contained in plastic vessels.

All leaching contacts and solution samples within the procedure are held in plastic vessels to minimize uranium contamination leached from glassware. The steps in the selective dissolution technique are diagrammed in Figure 2.1.

(a) Some of the early testing only used a single contact with $\mathrm{Na}_{2} \mathrm{SO}_{4}$-bearing $\mathrm{H}_{3} \mathrm{PO}_{4}$ and was done without vortex mixing. 


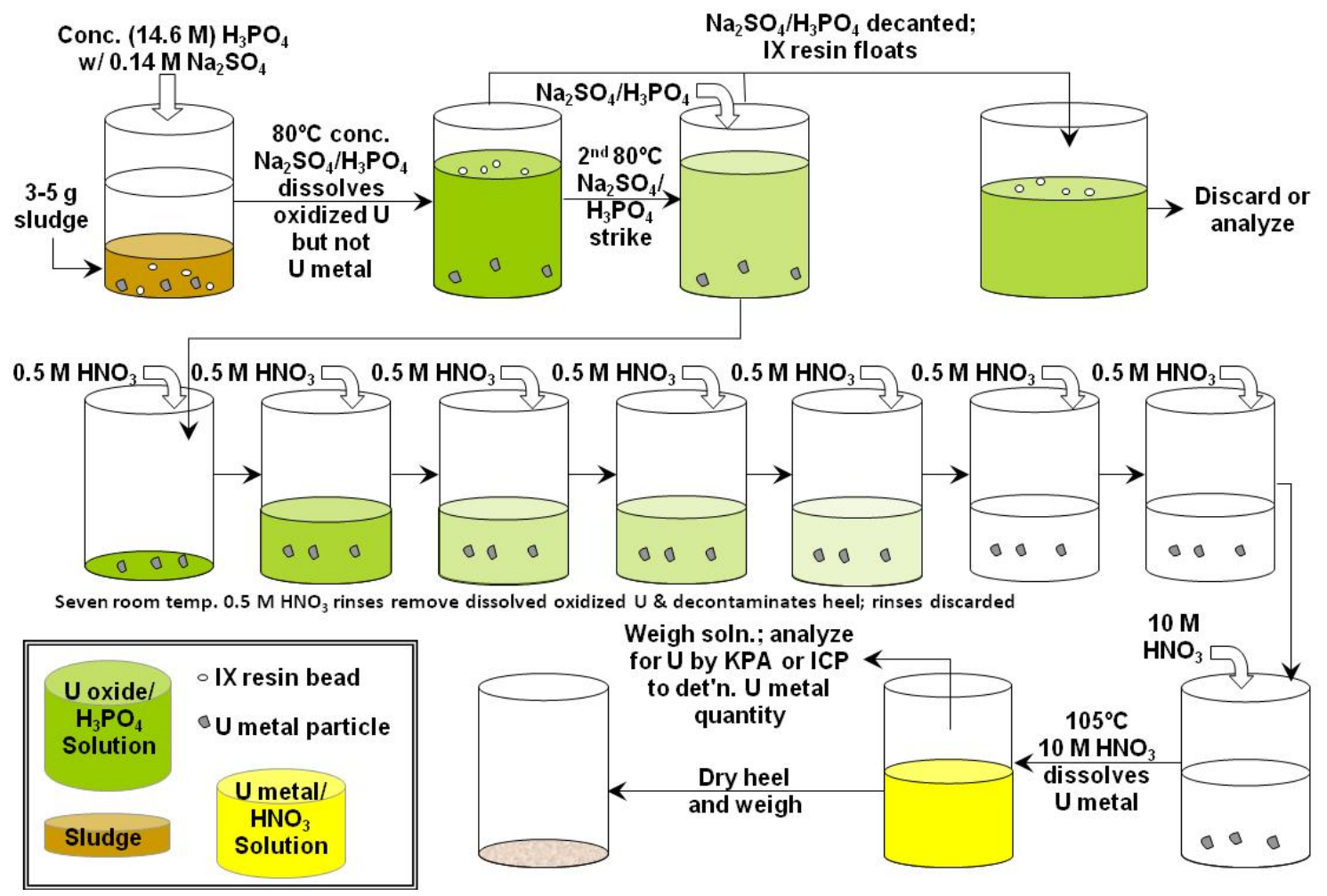

Figure 2.1. Block Flow Diagram for Selective Dissolution Analysis of Uranium Metal in Sludge

1) Uranium oxide dissolution in $80^{\circ} \mathrm{C}$ concentrated $\mathrm{H}_{3} \mathrm{PO}_{4}$ with $0.14 \mathrm{M} \mathrm{Na}_{2} \mathrm{SO}_{4}$; $\mathrm{U}$ metal does not dissolve. Intermittent vortex mixing used to improve acid/solid contact and dissolution.

2) Rinsing of dissolved oxidized uranium from remaining solids with room temperature $0.5 \mathrm{M} \mathrm{HNO}_{3}$. Vortex mixing was used in the $1^{\text {st }}, 3^{\text {rd }}, 5^{\text {th }}$, and $7^{\text {th }}$ contacts to improve solids leaching and rinse vessel walls.

3) Dissolution of uranium metal in $105^{\circ} \mathrm{C} 10 \mathrm{M} \mathrm{HNO}_{3}$. 


\subsection{Technical Challenges Identified for Implementing the Selective Dissolution Approach}

The proposed analysis must successfully address several technical challenges to attain the goal sensitivity of measuring $0.03 \mathrm{wt} \%$ uranium metal in the sludge. This measurement target is driven by flammable gas-generation limits in an RH-72B transuranic waste transportation container during transit to the Waste Isolation Pilot Plant (WIPP). The uranium metal concentration in the sludge will also affect sludge processing strategies and approaches to onsite storage and shipment of grouted sludge.

- The analysis must be capable of measuring uranium metal concentrations of $0.03 \mathrm{wt} \%$ (or lower; i.e., order of magnitude less than design-basis KE Floor sludge of $0.26 \mathrm{wt} \%$ ). This uranium metal concentration is at least 1000 times lower than the total uranium concentration in some sludge (i.e., some sludge may contain $>30 \mathrm{wt} \%$ total uranium).

- To detect the small amounts of uranium metal in many sludges, essentially all of the oxidized uranium compounds (e.g., uraninite, $\mathrm{UO}_{2}$; metaschoepite, $\mathrm{UO}_{3} \cdot 2 \mathrm{H}_{2} \mathrm{O}$ ) must first be dissolved and removed before dissolving the uranium metal.

- The oxidized uranium removal must be achieved with minimal dissolution of the uranium metal.

- Organic ion exchange resin (OIER) beads and the mordenite inorganic ion exchange material (IXM) also present in the sludge may sorb dissolved uranium. Neither the OIER beads nor the mordenite are visibly attacked by acid digestion, but either may release or sorb uranium during the $10-\mathrm{M} \mathrm{HNO}_{3}$ treatment used to dissolve the uranium metal. Therefore, the effects of these ion exchangers must be determined.

An additional challenge in implementing the selective dissolution technique is in attaining low detection limits in the presence of high and ubiquitous uranium contamination levels in the analytical and process hot cells. As will be shown, testing also indicated that a difficult-to-dissolve precipitate formed upon adding the $\mathrm{Na}_{2} \mathrm{SO}_{4}$-bearing $\mathrm{H}_{3} \mathrm{PO}_{4}$ solution to the sludge. Subsequent testing showed that this precipitate could be dissolved but required vigorous mixing and a second $\mathrm{Na}_{2} \mathrm{SO}_{4} / \mathrm{H}_{3} \mathrm{PO}_{4}$ strike.

\subsection{Dissolution of Uranium, Iron, and Aluminum Phases in Phosphoric Acid}

The ratio of sludge to $\mathrm{Na}_{2} \mathrm{SO}_{4} / \mathrm{H}_{3} \mathrm{PO}_{4}$ must be as great as possible to improve method sensitivity but not so great that iron, aluminum, and particularly the uranium-phase dissolution cannot be achieved. For example, if $3 \mathrm{~mL}$ ( $\sim 6 \mathrm{~g}$ ) of the most uranium-rich sludge in the sludge archive inventory, KC-1 M500 $\left(46.3 \mathrm{wt} \% \mathrm{U}\right.$ and $2.05 \mathrm{~g} / \mathrm{cm}^{3}$ density as-settled ${ }^{(\mathrm{a})}$ ), were to be dissolved in concentrated $(14.6 \mathrm{M}) \mathrm{H}_{3} \mathrm{PO}_{4}$ to

(a) CH Delegard, AJ Schmidt, and JW Chenault. 2007. Characteristics of KE Basin Sludge Samples Archived in the RPL - 2007, Letter Report 53451-RPT01, PNNL-17078 (limited distribution) Pacific Northwest National Laboratory, Richland, WA. 
$\sim 35 \mathrm{~mL}$ total volume, the uranium concentration would be $\sim 0.35 \mathrm{M}$. Settled sludge is typically $\sim 75$ vol\% water, which will dilute the $\mathrm{H}_{3} \mathrm{PO}_{4}$ concentration about $10 \%$.

The solubility of $\mathrm{U}(\mathrm{VI})$ in $12.7 \mathrm{M} \mathrm{H}_{3} \mathrm{PO}_{4}$ is at least $0.48 \mathrm{M}$ at $25^{\circ} \mathrm{C}$, and the $\mathrm{U}(\mathrm{IV})$ solubility in $14 \mathrm{M}$ $\mathrm{H}_{3} \mathrm{PO}_{4}$ is $\sim 1 \mathrm{M}$ with both solubilities increasing with increasing temperature (Thamer et al. 1956). Therefore, the selected dissolution conditions are sufficient to dissolve all of the U(IV) and U(VI) phases even for the high uranium KC-1 M500 sludge. Complete dissolution of all U(IV) and U(VI) phases is necessary in light of the selective dissolution technique goal to leave uranium metal as the only uranium source in the $\mathrm{H}_{3} \mathrm{PO}_{4}$-leached sludge. For the $\mathrm{KC}-2 / 3$ sludge used in the present testing, $34.8 \mathrm{wt} \%$ of the sludge is $\mathrm{U}$ on an as-settled (wet) basis, and the density is $2.03 \mathrm{~g} / \mathrm{cm}^{3}$ to give a projected $\sim 0.23-\mathrm{M}$ uranium concentration in the $\mathrm{H}_{3} \mathrm{PO}_{4}$ solution.

At the same time, uranium metal should not be significantly dissolved by the same treatment with the mixed $\mathrm{Na}_{2} \mathrm{SO}_{4} / \mathrm{H}_{3} \mathrm{PO}_{4}$ reagent. Preliminary tests showed that sub-millimeter-diameter uranium metal beads required 11 days to dissolve in $130^{\circ} \mathrm{C}$ concentrated $\mathrm{H}_{3} \mathrm{PO}_{4}$ for a penetration rate of $<2 \mu \mathrm{m} /$ hour. Even lower metal penetration rates are expected at the $\sim 80^{\circ} \mathrm{C}$ temperatures to be used in the sludge dissolution with $\mathrm{Na}_{2} \mathrm{SO}_{4} / \mathrm{H}_{3} \mathrm{PO}_{4}$. Uranium metal penetration rates under sludge dissolution conditions were measured in the present testing.

Iron is the metallic element found in greatest molar concentrations in both FE-5 and KE Floc Comp test sludges used in the present tests. The dissolution of the precipitated iron (hydr)oxide phases (such as $\mathrm{FeOOH}$ ), which may occlude or coprecipitate uranium present in the sludge aliquots, is essential in removing all oxidized uranium phases from the sludge before the later dissolution of the $\mathrm{H}_{3} \mathrm{PO}_{4}$-resistant uranium metal from the heel. Dissolving $3 \mathrm{~mL}$ of the iron-rich ( $\sim 31 \mathrm{wt} \%$, dry basis) FE-5 sludge to $\sim 35 \mathrm{~mL}$ total volume will produce an $\sim 0.46-\mathrm{M}$ iron solution. Prior tests show that iron(III) in strong $\mathrm{H}_{3} \mathrm{PO}_{4}$ solution will be saturated at $\sim 0.75 \mathrm{M}$. Therefore, the dissolution conditions should be adequate to dissolve the iron (hydr)oxide sludge phases present in any sludge tested in the present experiments.

Because aluminum concentrations in the sludge are lower, and aluminum is more soluble in $\mathrm{H}_{3} \mathrm{PO}_{4}$ than is iron (Brosheer et al. 1954), aluminum (hydr)oxide phases also should dissolve completely. Both aluminum and iron phosphates show increased solubility in $\mathrm{H}_{3} \mathrm{PO}_{4}$ with increasing temperature. Although some attack of accompanying soil minerals (e.g., basalt sand, anorthite) by $\mathrm{Na}_{2} \mathrm{SO}_{4} / \mathrm{H}_{3} \mathrm{PO}_{4}$ is expected, the dissolution of aluminum and iron phases present from these minerals is not required as the minerals native to Hanford and the sand introduced intentionally to the Basins for depth filters have negligible associated uranium.

\subsection{Ion Exchange Behavior of K Basin Sludge Solids}

Solids, including inorganic minerals and metals (e.g., silica, Zircaloy), the inorganic ion exchanger sodium mordenite $\left[\left(\mathrm{Ca}, \mathrm{Na}_{2}, \mathrm{~K}_{2}\right) \mathrm{Al}_{2} \mathrm{Si}_{10} \cdot 7 \mathrm{H}_{2} \mathrm{O}\right.$; Norton Zeolon 900$]$ used in the $\mathrm{K}$ Basins to decrease ${ }^{137} \mathrm{Cs}$ concentrations, and the mixed strong-acid/strong-base OIER (Purolite NRW-37) also used in Basin waterquality operations are not expected to be dissolved by $\mathrm{Na}_{2} \mathrm{SO}_{4} / \mathrm{H}_{3} \mathrm{PO}_{4}$ or the succeeding dilute $\mathrm{HNO}_{3}$ rinses. 
Although uranium solution concentrations are low in the K Basins sludge, some absorption onto solids could have occurred. However, in the acid dissolution steps, uranium solution concentrations will be much greater, with a greater likelihood of absorption onto solids including the mordenite and OIER. In strong $\mathrm{H}_{3} \mathrm{PO}_{4}$, the dissolved uranium potentially is present as anionic, cationic, or neutral $\mathrm{U}(\mathrm{IV})$ and $\mathrm{U}(\mathrm{VI})$ complexes of the form $\mathrm{U}\left(\mathrm{HPO}_{4}\right)_{\mathrm{x}}{ }^{(2 \mathrm{x}-4)-}$ and $\mathrm{UO}_{2}\left(\mathrm{HPO}_{4}\right)_{\mathrm{x}}{ }^{(2 \mathrm{x}-2)-}$, respectively. In strong $\mathrm{HNO}_{3}$, any $\mathrm{U}(\mathrm{IV})$ is oxidized to $\mathrm{U}(\mathrm{VI})$ and cationic, neutral, or anionic nitrate $\mathrm{U}(\mathrm{VI})$ complexes of the form $\mathrm{UO}_{2}\left(\mathrm{NO}_{3}\right)_{\mathrm{x}}{ }^{(\mathrm{x}-2)-}$ exist. As potentially charged species, the dissolved uranium may sorb on the solid surfaces, particularly the IXM, and affect the outcome of the uranium metal concentration determination. Therefore, this uranium must be removed from the solids during the sludge dissolution in concentrated $\mathrm{H}_{3} \mathrm{PO}_{4}$ solution and in succeeding rinse steps in dilute $\mathrm{HNO}_{3}$.

Information on the distribution of uranium onto mordenite from $\mathrm{HNO}_{3}$ or other acid solution is limited but points to low sorption from acid solution. The $\mathrm{K}_{\mathrm{d}}$ of $\mathrm{U}(\mathrm{VI})$ onto mordenite as a function of $\mathrm{pH}$ decreases with decreasing $\mathrm{pH}$ as shown in Figure 3.1 (Reddy and Cai 1996, pp. 1173-1179). The $\mathrm{K}_{\mathrm{d}} \mathrm{s}$ for divalent strontium $(\mathrm{Sr})$ and cobalt $(\mathrm{Co})$ and trivalent cerium $(\mathrm{Ce})$, europium $(\mathrm{Eu})$, terbium $(\mathrm{Tb})$, and iron (Fe) on Zeolon 900 (mordenite), also plotted in Figure 3.1, show similarly decreasing $\mathrm{K}_{\mathrm{d}} \mathrm{S}$ with decreasing $\mathrm{pH}$ (Kanno and Mimura 1985, pp. 237-247). Over the same pH 1 to 5 range, the $\mathrm{K}_{\mathrm{d}}$ for cesium (Cs) onto mordenite is high $(\sim 10,000 \mathrm{~mL} / \mathrm{g})$ and relatively invariant. Mordenite is selective for cesium ion because the diameter within mordenite's zeolitic channel structure is suited to cesium's ionic diameter. The data in Figure 3.1 for the seven metals, including those of uranium, all trend to decreasing absorption as $\mathrm{pH}$ decreases. As a result, the sorption of uranium onto mordenite in $\mathrm{HNO}_{3}$ solution is expected to be low.

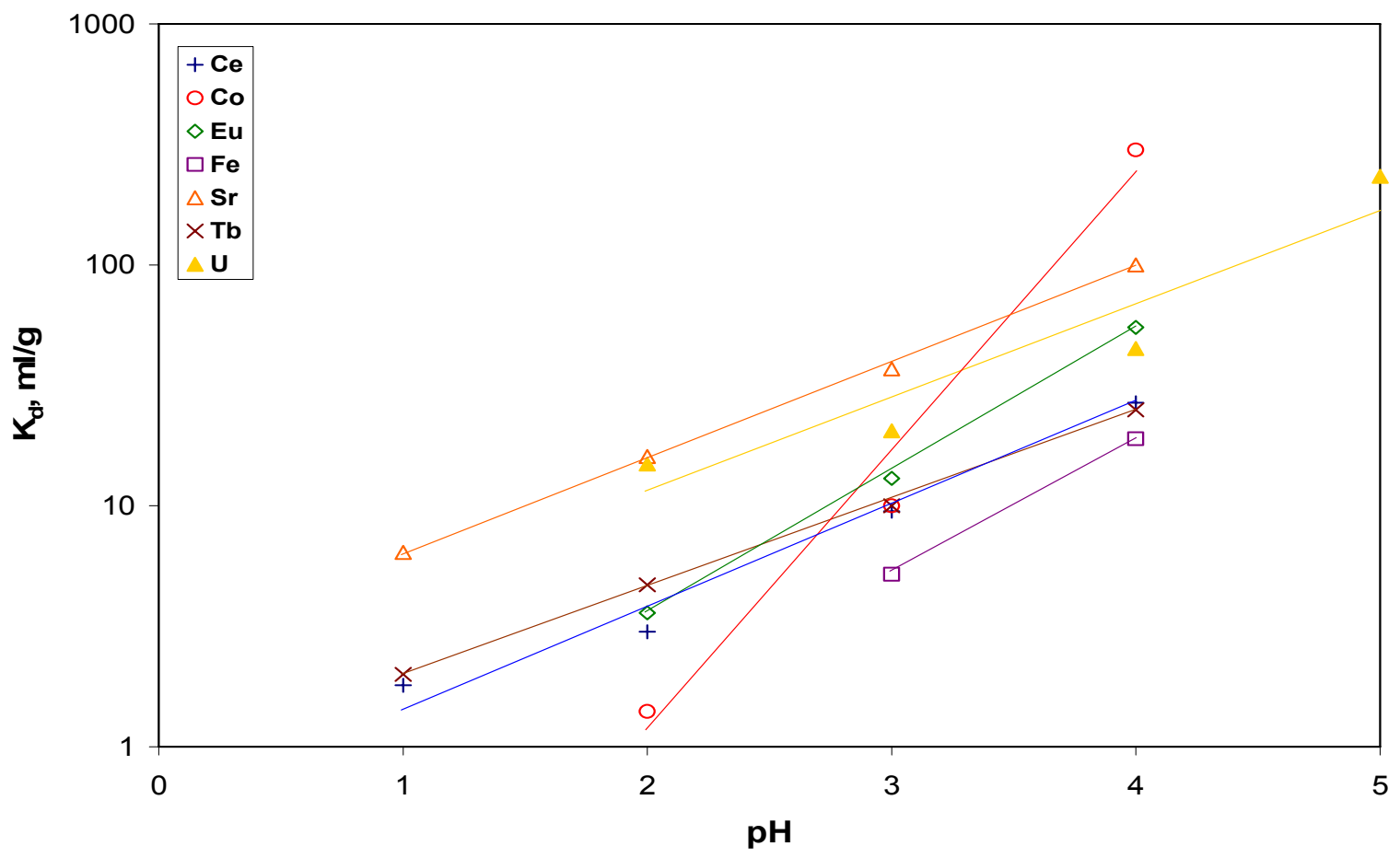

Figure 3.1. Distribution Coefficients, $\mathrm{K}_{\mathrm{d}} \mathrm{s}$, for Various Metals onto Mordenite as Functions of $\mathrm{pH}$ 
Uranium uptake from $\mathrm{HNO}_{3}$ solution onto mordenite and other sorbents was examined (Marsh et al. 1994). In the mordenite tests, an acidified aliquot of Hanford tank 102-SY simulant (containing $0.5 \mathrm{M}$ $\mathrm{HNO}_{3}, 0.65 \mathrm{M}$ sodium, $0.43 \mathrm{M}$ aluminum, $0.36 \mathrm{M}$ iron, $0.023 \mathrm{M}$ uranium, and others) was contacted with beads of polyacrylonitrile-bound synthetic mordenite powder at a ratio of 6-mL solution to $0.25 \mathrm{~g}$ of solid. The synthetic mordenite comprised $93 \%$ of the total bead weight. The uranium $\mathrm{K}_{\mathrm{d}}$ values were 0.4 , 0.6 , and $0.4 \mathrm{~mL} / \mathrm{g}$ after $0.5-, 2-$, and 6-hours contact, respectively. Of the 14 elements whose uptakes were studied, only cesium and zirconium showed significant sorption.

Because of their high exchange capacities, the OIER are of most concern for uranium uptake and have been shown, in tests with genuine $\mathrm{K}$ Basin sludge containing both OIER and OIER with mordenite, to retain uranium to a limited degree (Schmidt et al. 1999; Delegard and Rinehart 1998; Delegard et al. 1998). The distribution coefficients $\left(\mathrm{K}_{\mathrm{d}}\right)$ calculated for uranium in one of these studies were about $0.1 \mathrm{~mL} / \mathrm{g}$ on mordenite and about $0.5 \mathrm{~mL} / \mathrm{g}$ on the mixed organic resin in $\mathrm{HNO}_{3}$ solutions of $\mathrm{K}$ Basin sludge also containing $\sim 0.52 \mathrm{M}$ iron and $\sim 0.16 \mathrm{M}$ aluminum in $\sim 4 \mathrm{M} \mathrm{HNO}_{3}$. Under less competitive conditions (i.e., with lower or negligible concentrations of other metals, such as iron and aluminum, to compete with the uranium for ion exchange sites), the $\mathrm{K}_{\mathrm{d}} \mathrm{s}$ for the undifferentiated (mixed) inorganic and organic IXM did not change appreciably with difference in acid composition and were about $4 \mathrm{~mL} / \mathrm{g}$ in

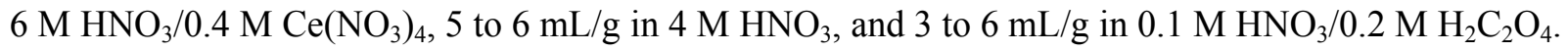
In comparison, the $\mathrm{K}_{\mathrm{d}}$ of $\mathrm{U}(\mathrm{VI})$ onto strong-base anion exchange resin is $3.9 \mathrm{~mL} / \mathrm{g}$ at $7 \mathrm{M} \mathrm{HNO}_{3}$ (Weigel et al. 1986).

These data show that uranium sorption onto the IXM present in many of the $\mathrm{K}$ Basins sludges is low and that the two $\mathrm{Na}_{2} \mathrm{SO}_{4} / \mathrm{H}_{3} \mathrm{PO}_{4}$ sludge dissolution contacts followed by seven dilute $\mathrm{HNO}_{3}$ rinses will further decrease the uranium retention. ${ }^{\text {(a) }}$ Under the envisioned sequence of sludge dissolution by strong $\mathrm{H}_{3} \mathrm{PO}_{4}$ followed by rinsing of the heels with dilute $\mathrm{HNO}_{3}$, the IXM residues should retain little of the oxidized uranium. However, the IXM also could absorb some of the uranium dissolved from the metal in the final strong $\mathrm{HNO}_{3}$ dissolution step and complicate the interpretation of the uranium concentration data. Fortunately, the OIER will float in the dense concentrated $\mathrm{Na}_{2} \mathrm{SO}_{4} / \mathrm{H}_{3} \mathrm{PO}_{4}$ solution and thus may be readily separated from the remaining denser solids heels (sand, Zircaloy cladding, mordenite, U metal) when the $\mathrm{Na}_{2} \mathrm{SO}_{4} / \mathrm{H}_{3} \mathrm{PO}_{4}$ solutions are decanted. The retention of uranium on mordenite must be tested.

\subsection{Uranium Metal Dissolution in Nitric Acid}

In the selective dissolution technique, uranium metal and other heel solids are rinsed with cell temperature $0.5 \mathrm{M} \mathrm{HNO}_{3}$ to remove interstitial solutions from oxidized uranium dissolution in $\mathrm{Na}_{2} \mathrm{SO}_{4} / \mathrm{H}_{3} \mathrm{PO}_{4}$. The rinsed solids then are treated with $105^{\circ} \mathrm{C} 10 \mathrm{M} \mathrm{HNO}_{3}$ to dissolve the uranium metal in preparation for analysis. The selection of these $\mathrm{HNO}_{3}$ concentrations and temperatures arises from consideration of the uranium metal dissolution rate under these widely differing conditions. Optimally, no uranium metal dissolution should occur in the $0.5-\mathrm{M} \mathrm{HNO}_{3}$ rinse while the metal completely dissolves in the $10-\mathrm{M}$ $\mathrm{HNO}_{3}$ treatment.

(a) For example, at a nominal $\mathrm{K}_{\mathrm{d}}$ of $0.5 \mathrm{~mL} / \mathrm{g}$ and $0.5 \mathrm{~g}$ of solids being washed with $10 \mathrm{~mL}$ of solution, each contact would remove $\sim 97.6 \%$ of the uranium. Three such contacts would remove $\sim 99.999 \%$ of the uranium. If the $\mathrm{K}_{\mathrm{d}}$ were $5 \mathrm{~mL} / \mathrm{g}, 99.2 \%$ would be removed in three contacts, and $\sim 99.999 \%$ would be removed in seven contacts. Seven $0.5-\mathrm{M} \mathrm{HNO}_{3}$ rinse contacts are used in the present testing. 
The uranium metal dissolution rate in nitric acid solution increases with increasing temperature. The rate also increases with increasing nitric acid, or total nitrate, concentrations. The dissolution rate of uranium metal in $3 \mathrm{M}$ to $12 \mathrm{M} \mathrm{HNO}_{3}$ at $25^{\circ} \mathrm{C}$ was studied (Lacher et al. 1961). The rate decreases by a factor of $\sim 300,000$ per decade decrease in $\mathrm{HNO}_{3}$ concentration in this range and is about $5 \times 10^{-4} \mu \mathrm{m} /$ hour in $3 \mathrm{M}$ $\mathrm{HNO}_{3}$. Even for a $1-\mu \mathrm{m}$-diameter uranium metal particle, which has a mass of $\sim 10^{-11}$ grams, uranium dissolution would be negligible (i.e., the initial $1.000 \mu \mathrm{m}$ diameter would decrease to $0.999 \mu \mathrm{m}$ ) in $3 \mathrm{M}$ $\mathrm{HNO}_{3}$ in the estimated 1 hour time needed to accomplish the seven $0.5 \mathrm{M} \mathrm{HNO}_{3}$ rinses. Therefore, treatment of uranium metal particles in the sludge heel with the even more dilute $0.5 \mathrm{M} \mathrm{HNO}_{3}$ should have a negligible effect on uranium metal recovery.

The dissolution rates of uranium metal in boiling $\mathrm{HNO}_{3}$ solutions as a function of total nitrate concentration $\left(\mathrm{HNO}_{3}\right.$ plus uranyl nitrate and other metal nitrates) are shown in Figure 3.2. It is seen that the dissolution rate of uranium metal in $10 \mathrm{M} \mathrm{HNO}_{3}$ is about $500 \mu \mathrm{m} /$ hour. Two hours of treatment with near boiling $10 \mathrm{M} \mathrm{HNO}_{3}$ should dissolve a 2000 - $\mu \mathrm{m}$-diameter uranium particle and thus dissolve most uranium metal particles expected in bulk floor and canister sludge. ${ }^{\text {(a) }}$ Larger particles of uranium metal, such as from KOP sludge, would be readily observed in handling the sludge heel after the $\mathrm{Na}_{2} \mathrm{SO}_{4} / \mathrm{H}_{3} \mathrm{PO}_{4}$ and subsequent $0.5 \mathrm{M} \mathrm{HNO}_{3}$ treatments and would require special treatment. Sludge is defined as material from the $\mathrm{K}$ Basins passing a 1/4-inch screen. A 1/4-inch-diameter uranium metal sphere weighs about 2.6 grams and thus would constitute a significant portion of the 3- to 5-gram sludge sample weight.

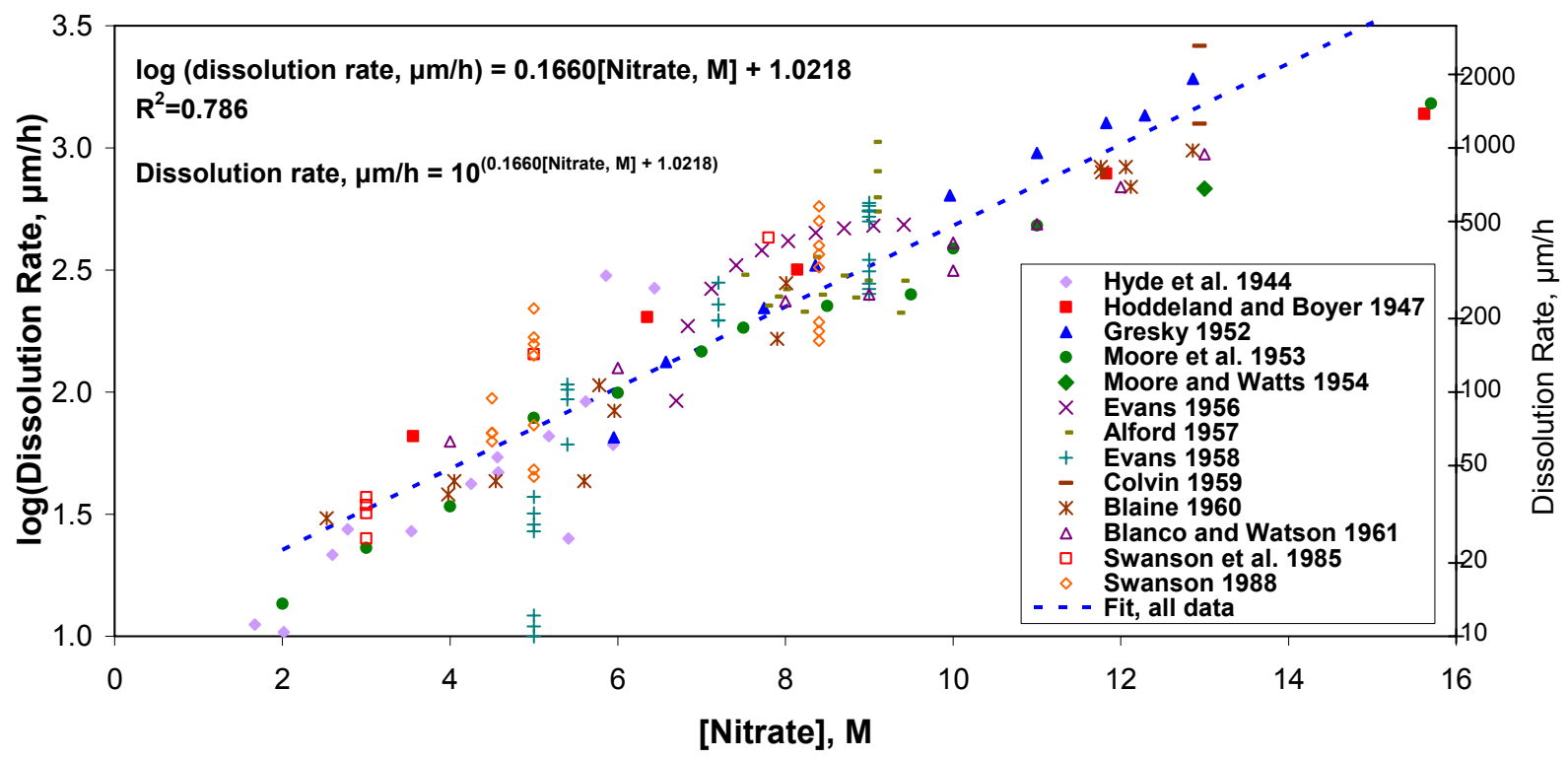

Figure 3.2. Dependence of Uranium Metal Dissolution Rate on Total Nitrate Concentration at Boiling

(a) The nominal diameter of uranium metal observed in KC-2/3 P250 sludge is $\sim 800 \mu \mathrm{m}$ (Delegard et al. 2000). The kinetic data from that study have been re-analyzed using the STP rate equation (Appendix G of Plys and Schmidt 2006) to show that the nominal uranium metal diameter is $\sim 560 \pm 28 \mu \mathrm{m}$. 
The capacity of $10 \mathrm{~mL}$ of $10 \mathrm{M} \mathrm{HNO}_{3}$ is sufficient to dissolve 4 grams of uranium metal based on the least effective reaction stoichiometry to form $\mathrm{NO}_{2}$ from $\mathrm{HNO}_{3}$ chemical reduction:

$$
\mathrm{U}+8 \mathrm{HNO}_{3} \rightarrow \mathrm{UO}_{2}\left(\mathrm{NO}_{3}\right)_{2}+6 \mathrm{NO}_{2}+4 \mathrm{H}_{2} \mathrm{O}
$$

Therefore, $\mathrm{HNO}_{3}$ is available in at least a 10 -fold stoichiometric excess for metal dissolution from a 4-gram sample of settled sludge containing $10 \mathrm{wt} \%$ uranium metal (or $\sim 20 \mathrm{wt} \%$ uranium metal on a dry sludge basis). Most sludge, except for knock-out pot (KOP) sludge, is expected to have much lower uranium metal concentrations. 


\subsection{Experiments for Uranium Metal Dissolution Rate and Analysis of Uranium Metal Concentration in Simulated Sludge}

In the initial development of the selective dissolution technique for actual $\mathrm{K}$ Basin sludge, laboratory work was conducted to determine the rate of uranium metal dissolution in concentrated $\mathrm{H}_{3} \mathrm{PO}_{4}$ solution at $80^{\circ} \mathrm{C}$. Samples were taken periodically over 24 hours of reaction to determine the rate of dissolution of uranium metal present as sub-millimeter-diameter beads.

Testing with simulated sludge was performed to determine the efficacy of the rinses from sludge residues and to investigate the effects of ion exchange materials on the method sensitivity. The dry simulated sludge contained uranium dioxide $\left(\mathrm{UO}_{2}\right.$ at $\left.22 \mathrm{wt} \%\right)$, sand (blow sand from the Arid Lands Ecology, ALE, reserve adjacent to the Hanford Site, at $\sim 21 \mathrm{wt} \%$ ), aluminum hydroxide $\left[\mathrm{Al}(\mathrm{OH})_{3}\right.$, gibbsite, at $17 \mathrm{wt} \%$, iron hydroxide $\left[\mathrm{FeOOH}\right.$ added as $\mathrm{Fe}_{5} \mathrm{O}_{7}(\mathrm{OH}) \cdot 4 \mathrm{H}_{2} \mathrm{O}$, ferrihydrite, equivalent to $\mathrm{FeOOH} \cdot 0.4 \mathrm{H}_{2} \mathrm{O}$, at $40 \mathrm{wt} \%$, and 0,1 , or 4 carefully weighed $\mathrm{U}$ metal beads. The $\mathrm{UO}_{2}$ was prepared separately by the corrosion of uranium metal in anoxic liquid water at $60^{\circ} \mathrm{C}$ (Sinkov et al. 2008). These summed dry weights were complemented by a matching weight of added water (i.e., the simulated sludge was $50 \mathrm{wt} \%$ water). The composition of the simulated sludge is shown in Table 4.1.

Table 4.1. Composition of Simulated Sludge

\begin{tabular}{|c|c|c|}
\hline Component & Weight, g & Weight \% \\
\hline $\mathrm{Al}(\mathrm{OH})_{3}$ & 12.751 & 8.498 \\
\hline $\mathrm{FeOOH}$ & 30.002 & 19.996 \\
\hline $\mathrm{ALE} \mathrm{Blow} \mathrm{Sand}$ & 15.756 & 10.501 \\
\hline $\mathrm{UO}_{2}$ & 16.502 & 10.998 \\
\hline Water & 75.028 & 50.006 \\
\hline
\end{tabular}

Selected tests were run with mixed-bed, strong acid/strong base OIER. The OIER used was Purolite NRW-37, the same as has been used in the K Basins. Powdered inorganic sodium mordenite IXM also was added to the simulated sludge. The original mordenite IXM used in the K Basins water treatment was granular Norton Zeolon 900. Because Zeolon 900 was no longer available, (UOP LLC) molecular sieve LZM-5, a sodium mordenite in powder form, was used. The amounts of IXM added were relatively high, corresponding to about $0.1 \mathrm{~g}$ of each of the organic and inorganic IXM per $\sim 3 \mathrm{~g}$ of wet simulated sludge or about $3 \mathrm{wt} \%$ for each type of IXM. The simulated sludge compositions, including added uranium metal, OIER, and mordenite, are presented in Table 4.2. 
Table 4.2. Compositions of Test Items Prepared with Simulant Sludge, Uranium Metal, and IXM

\begin{tabular}{||l|c|c|c|c||}
\hline \multirow{2}{*}{$\begin{array}{c}\text { Test } \\
\text { Identification }\end{array}$} & \multicolumn{4}{|c||}{ Component Weight, $\mathbf{g}$} \\
\cline { 2 - 5 } & Sludge $^{(\mathbf{a})}$ & $\begin{array}{c}\text { Uranium } \\
\text { Metal }\end{array}$ & OIER & Mordenite \\
\hline S-Blank & 3.129 & 0.0 & 0.0 & 0.0 \\
\hline S-1 & 3.092 & 0.00094 & 0.0 & 0.0 \\
\hline S-1 Dup & 3.130 & 0.00078 & 0.0 & 0.0 \\
\hline S-4 & 3.168 & 0.00769 & 0.0 & 0.0 \\
\hline SX-Blank & 2.919 & 0.0 & 0.100 & 0.103 \\
\hline SX-1 & 3.156 & 0.00195 & 0.102 & 0.102 \\
\hline SX-1 Dup & 3.194 & 0.00252 & 0.101 & 0.103 \\
\hline SX-4 & 3.093 & 0.01246 & 0.100 & 0.102 \\
\hline (a) Sludge composition given in Table 4.1. \\
\hline \multicolumn{5}{|l|}{} \\
\hline
\end{tabular}

The tests were completed under an approved test instruction. ${ }^{(b)}$ The dissolutions were performed according to the sequence identified in Figure 2.1 (although with only one $\mathrm{Na}_{2} \mathrm{SO}_{4} / \mathrm{H}_{3} \mathrm{PO}_{4}$ contact) with plastic vessels used throughout to eliminate uranium leaching from glass as a contamination source. The uranium concentration analyses were performed using kinetic phosphorescence analysis (KPA) under an approved analytical procedure. ${ }^{(c)}$

(b) $\mathrm{CH}$ Delegard. 2007. "Development of Alternative Method to Determine Uranium Metal Concentration in Sludge in Support of the K Basin Sludge Treatment Project," 53451 TI04, Rev. 0, Pacific Northwest National Laboratory, Richland, WA.

(c) C Soderquist. 2001. "Uranium by Kinetic Phosphorescence Analysis," RPG-CMC-4014, Rev. 1, Pacific Northwest National Laboratory, Richland, WA. 


\subsection{Results for Uranium Metal Dissolution Rate and Analysis in Simulated Sludge}

The uranium metal linear penetration dissolution rate in $80^{\circ} \mathrm{C} \mathrm{Na}_{2} \mathrm{SO}_{4}$-bearing $\mathrm{H}_{3} \mathrm{PO}_{4}$ is $0.08 \mu \mathrm{m} /$ hour according to KPA measurements of the solution as a function of contact time. The corrosion rate plot is shown in Figure 5.1.

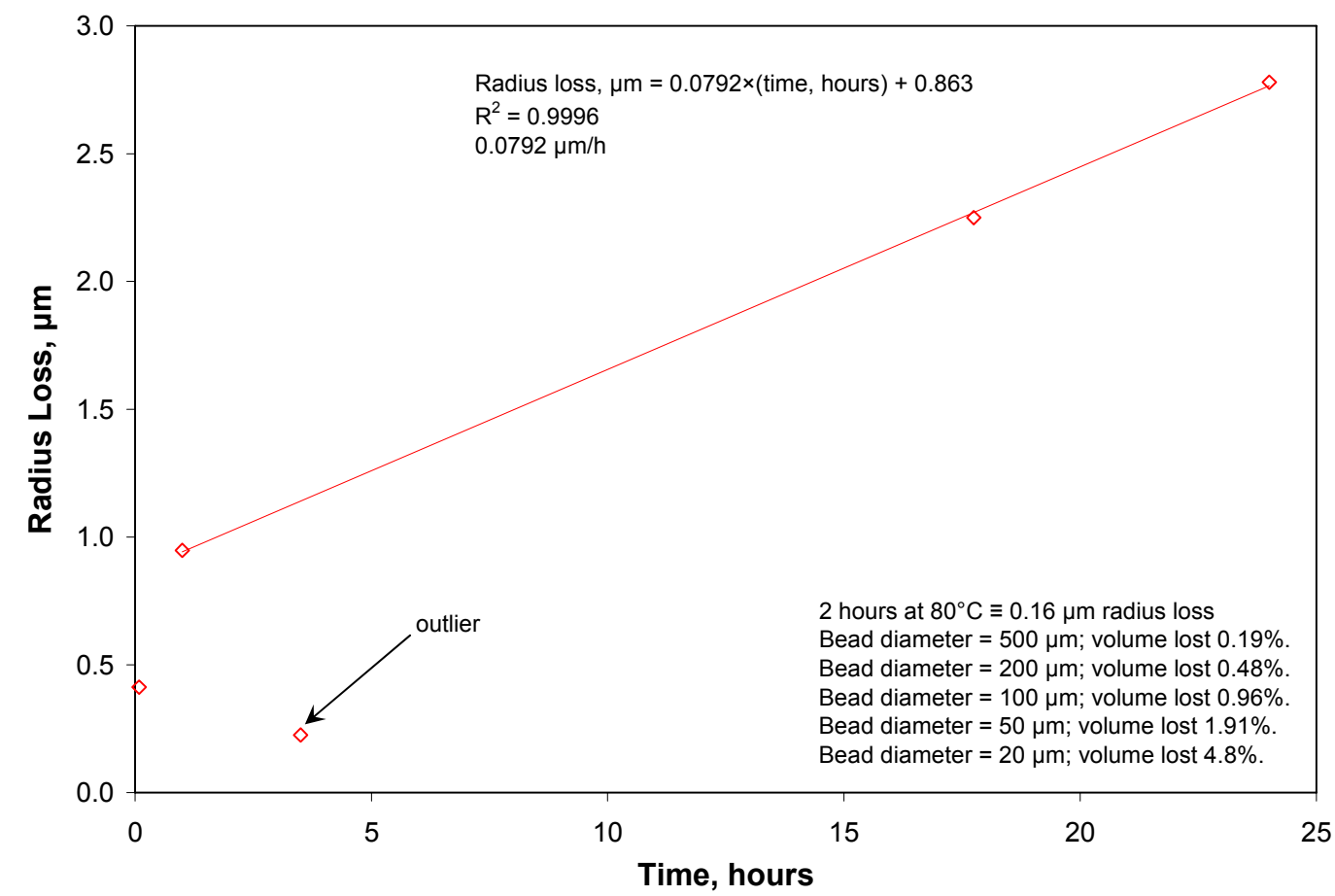

Figure 5.1. Uranium Metal Corrosion Rate in Concentrated $\mathrm{H}_{3} \mathrm{PO}_{4}$

As shown in Figure 5.1, this rate is sufficiently low to allow reliable uranium metal concentration determination even for 20 - $\mu \mathrm{m}$-diameter particles, well below the uranium metal particle sizes identified in prior gas-generation testing of the KC-2/3 P250 sludge (Delegard et al. 2000).

Analyses of the uranium concentrations found in the sixth and seventh $0.5-\mathrm{M} \mathrm{HNO}_{3}$ rinses and in the subsequent metal dissolution step with $10 \mathrm{M} \mathrm{HNO}_{3}$ are shown in Table 5.1. The sixth and seventh rinses are the last two in the rinse sequence and were analyzed to determine the completeness of oxidized uranium removal. 
Table 5.1. Uranium Concentrations in $0.5 \mathrm{M}$ Nitric Acid Rinses and in 10-M Nitric Acid Digestions for Simulated Sludge

\begin{tabular}{|c|c|c|c|c|}
\hline \multirow[b]{3}{*}{ Sludge Type } & \multirow[b]{3}{*}{ Sample } & \multicolumn{3}{|c|}{ بg U/mL (ppm) } \\
\hline & & \multicolumn{2}{|c|}{$0.5 \mathrm{M} \mathrm{HNO}_{3}$} & \multirow[b]{2}{*}{$10 \mathrm{M} \mathrm{HNO}_{3}$} \\
\hline & & $6^{\text {th }}$ Rinse & $7^{\text {th }}$ Rinse & \\
\hline \multirow{4}{*}{ Without IXM } & S-Blank & 0.209 & 0.335 & 22.8 \\
\hline & S-1 & 0.217 & 1.87 & 113 \\
\hline & S-1 Dup & 0.359 & 0.347 & 104 \\
\hline & \begin{tabular}{|l|}
$S-4$ \\
\end{tabular} & 0.306 & 0.424 & 778 \\
\hline \multirow{4}{*}{ With IXM } & SX-Blank & 0.412 & 0.448 & 35.5 \\
\hline & SX-1 & 0.834 & 0.931 & 214 \\
\hline & SX-1 Dup & 0.450 & 0.541 & 251 \\
\hline & \begin{tabular}{|l|} 
SX-4 \\
\end{tabular} & 0.501 & 0.758 & 1110 \\
\hline
\end{tabular}

It is seen that the single $\mathrm{Na}_{2} \mathrm{SO}_{4} / \mathrm{H}_{3} \mathrm{PO}_{4}$ dissolution contact and seven subsequent dilute $\mathrm{HNO}_{3}$ rinses efficiently removed the oxidized uranium and generally decreased the uranium concentration to less than $1 \mathrm{ppm}\left(\mu \mathrm{g}\right.$ of uranium per $\mathrm{mL}$ ) under conditions in which the initial $\mathrm{Na}_{2} \mathrm{SO}_{4} / \mathrm{H}_{3} \mathrm{PO}_{4}$ solution would have had uranium concentrations of about $8,000 \mathrm{ppm}$. The uranium concentrations in the two $10-\mathrm{M} \mathrm{HNO}_{3}$ blank test solutions were about 80 times higher than the prior $0.5-\mathrm{M} \mathrm{HNO}_{3}$ rinses for the test without added IXM and the test with added IXM. Although the OIER was largely removed by flotation in the $\mathrm{Na}_{2} \mathrm{SO}_{4}$-bearing $\mathrm{H}_{3} \mathrm{PO}_{4}$ contact, the inorganic IXM (mordenite) was not removed. Overall, however, as shown by comparing the data with and without IXM, the presence of IXM did not markedly affect uranium retention in the uranium metal-free simulated sludge solids.

The concentrations of uranium metal measured in the simulated sludge tests with and without added uranium metal and IXM are shown in Table 5.2 and in Figure 5.2. Analyses of the blank tests with no added metal were assayed to contain 0.0065- and 0.0103-wt $\%$ uranium metal, respectively, for simulated sludge without and with added IXM. Based on these values, the lower detection limits for uranium metal in the blank tests were around $0.01 \mathrm{wt} \%$ of the sludge. The uranium recoveries obtained for tests to which $\sim 0.03$ to $0.40 \mathrm{wt} \%$ of uranium metal were added were found to range from 80 to $119 \%$. Overall, recoveries were somewhat greater for the three tests without IXM $(103 \pm 20 \%)$ than for the three tests containing IXM $(90 \pm 10 \%)$, but the differences between these two data sets are not statistically significant. Hence, there was no discernable effect of the presence of IXM on the uranium recovery.

Table 5.2. Uranium Metal Analysis Results in U-Metal Spiked and Unspiked K Basin Sludge Simulant

\begin{tabular}{|l|c|c|c|c|c|c|c|c|c|c|c|}
\hline \multirow{3}{*}{ Sludge Type } & \multicolumn{9}{|c|}{ U Metal Concentration in Settled Sludge, wt\% } \\
\cline { 2 - 11 } & \multicolumn{2}{|c|}{ Blank } & \multicolumn{3}{|c|}{ Test 1 } & \multicolumn{3}{c|}{ Test 2 } & \multicolumn{3}{c|}{ Test 3 } \\
\cline { 2 - 11 } & Added & Found & Added & Found & \% Rec. & Added & Found & \% Rec. & Added & Found & \% Rec. \\
\hline Without IXM & 0.0000 & 0.0065 & 0.0303 & 0.0329 & 109 & 0.0250 & 0.0297 & 119 & 0.242 & 0.197 & 81 \\
\hline With IXM & 0.0000 & 0.0103 & 0.0580 & 0.0578 & 100 & 0.0741 & 0.0672 & 91 & 0.377 & 0.301 & 80 \\
\hline
\end{tabular}




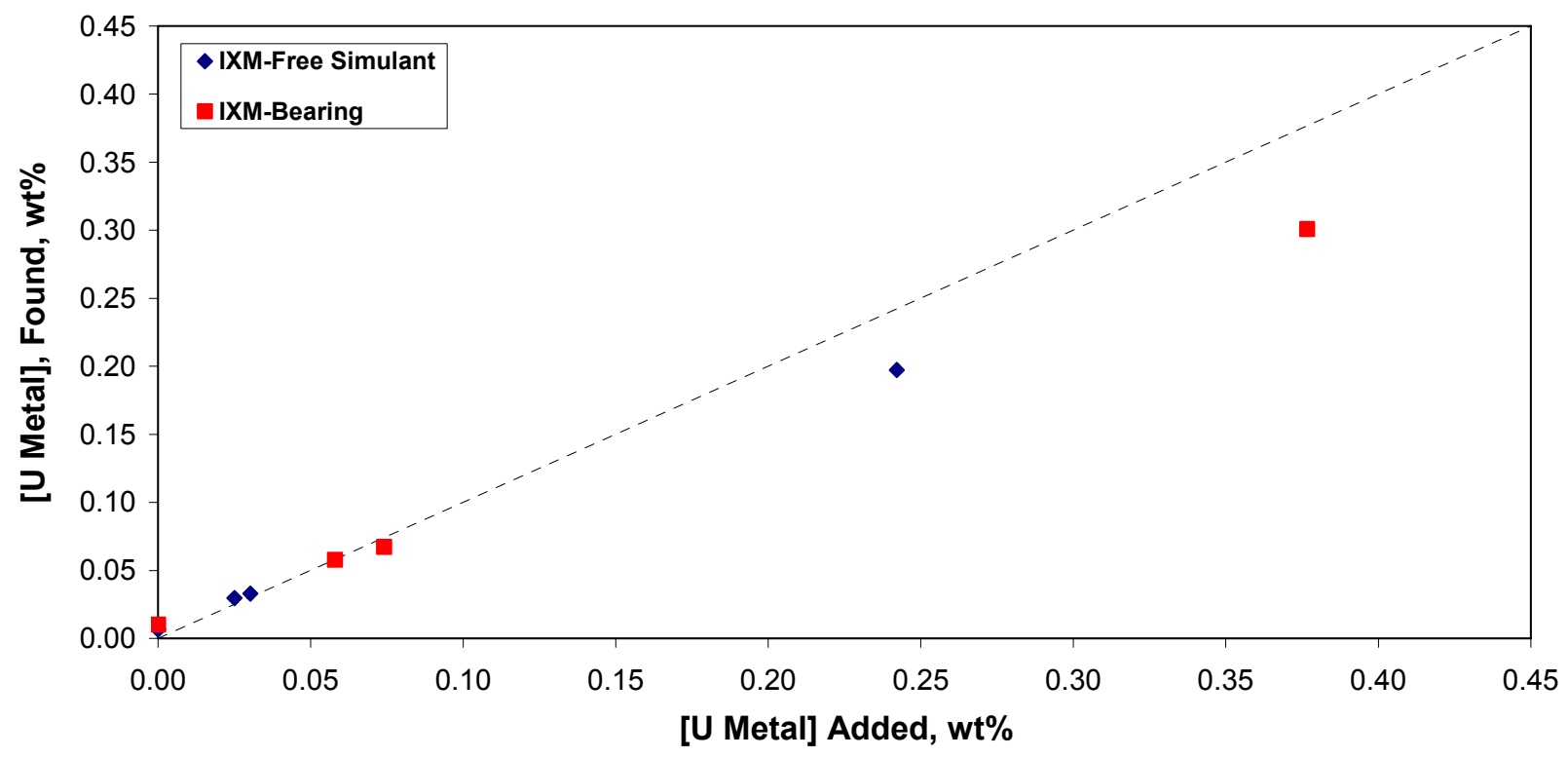

Figure 5.2. Uranium Metal Analysis Recoveries in Simulated Sludge

Analyses to quantify $\sim 0.03$ to $0.24 \mathrm{wt} \%$ uranium metal in settled sludge simulant without IXM showed uranium metal recoveries of about $86 \pm 7 \%$ when corrected for the blank analyses of the uranium metalfree simulated sludge. For sludge simulants containing both organic ion exchange resin and inorganic mordenite having $\sim 0.07$ to $0.40 \mathrm{wt} \%$ uranium metal, $\sim 80 \pm 3 \%$ uranium metal recovery, blank-corrected, was found.

Design basis KE Floor sludge contains $0.26 \mathrm{wt} \%$ uranium metal. The results for the testing with simulated sludge showed that the proposed uranium metal measurement procedure method gave satisfactory results. On this basis, testing with actual K Basin sludge spiked with known amounts of uranium metal was performed. 


\subsection{Experiments for Uranium Metal Analysis in K Basin Sludge}

Based on the promising findings with simulated sludge, tests of selective dissolution were performed for actual K Basin sludge containing known amounts of added uranium metal. The work was conducted under approved test instructions. ${ }^{(a)}$

A broad range of representative sludge compositions was tested. The FE-5 sludge, which originated from the KE Weasel Pit and South Loadout Pit, was tested because about one quarter of the total K Basin sludge volume is composed of the Weasel and South Loadout Pit sludge. The most uranium-rich sludge is that collected in Settler Tubes during fuel washing operations. However, because no sample of Settler Tube sludge exists in the laboratory, the Settler Tube sludge was represented by the uranium-rich KC-2/3 sludge. Most of the KE and KW sludge has been collected in five large containers located in the KW Basin. The KE Basin was the larger contributor to the volume of the containerized sludge. The KE Floc Comp sludge, a composite of floor, pit, and canister sludge retrieved from the KE Basin, was used to represent the entire containerized $\mathrm{K}$ Basin sludge inventory. This composite sludge also has been mixed with the same flocculating agent (Nalco Optimer 7194 Plus) and dosages as were used in K Basin sludge process transfers. The KE Floc Comp sludge is a blend of four sludges, including FE-5, plus three from canisters, including a small contribution from a composite of three canister sludges. The IXM materials (organic resin and mordenite) are potentially problematic sludge components. Therefore, a fourth sludge, KC-6, visibly rich in OIER and likely containing significant mordenite based on its sampling location, was added to KE Floc Comp sludge to determine the effects of IXM. The identities and properties of the four archived KE Basin sludge samples used in the testing are listed in Table 6.1. Further details on the sludge properties are provided in Table 6.2.

As shown in Table 6.1, the FE-5, KC-6, and KE Floc Comp sludges had 0.05 wt\% or lower uranium metal concentrations when they were analyzed in 1999 or 2000. These low uranium metal concentrations can only have decreased, likely to zero, by storage in the HLRF since their analyses $\sim 8$ years ago. However, the $\mathrm{KC}-2 / 3$ sludge, which contained $\sim 3.2 \mathrm{wt} \%$ uranium metal (dry basis) when analyzed in 1999, may still contain uranium metal.

Tests were performed both with and without known amounts of added uranium metal beads. The quantities of added uranium ranged from $\sim 0.006$ to $0.015 \mathrm{wt} \%$, settled sludge basis, for all sludge types. These tests were conducted according to the sequence shown in Figure 2.1 with a single 2-hour, $80^{\circ} \mathrm{C}$ contact with $\mathrm{Na}_{2} \mathrm{SO}_{4} / \mathrm{H}_{3} \mathrm{PO}_{4}$. As will be seen, the tests with sludge $\mathrm{KC}-2 / 3$ were repeated using two 2hour $/ 80^{\circ} \mathrm{C}$ contacts with $\mathrm{Na}_{2} \mathrm{SO}_{4} / \mathrm{H}_{3} \mathrm{PO}_{4}$ to improve oxidized uranium compound dissolution. Vortex agitation of the heated sludge mixtures with $\mathrm{Na}_{2} \mathrm{SO}_{4} / \mathrm{H}_{3} \mathrm{PO}_{4}$ was performed about every 15 minutes to

(a) CH Delegard. 2008. "Uranium Metal Analysis Testing for K East Basin Sludge Composites," 53451-TI06, Rev. 0, Pacific Northwest National Laboratory, Richland, WA.

CH Delegard. 2008. "Uranium Metal Analysis Testing for Higher Uranium Metal Concentrations in K East Basin Sludge Composite," 53451-TI09, Rev. 0, Pacific Northwest National Laboratory, Richland, WA. 
break up sludge agglomerates and enhance dissolution. Vortex mixing (rather than simple shaking) also was introduced to improve the $0.5-\mathrm{M} \mathrm{HNO}_{3}$ rinse contacts.

Table 6.1. KE Basin Samples Used in Testing

\begin{tabular}{|c|c|c|c|c|c|c|c|}
\hline \multirow[b]{2}{*}{$\begin{array}{l}\text { Sample } \\
\text { ID }\end{array}$} & \multirow[b]{2}{*}{ Source } & \multicolumn{5}{|c|}{ Dry Wt.\% } & \multirow[b]{2}{*}{$\begin{array}{l}\text { Wet } \\
\text { Density, } \\
\text { g/cm }\end{array}$} \\
\hline & & $\begin{array}{c}\text { Vol. Jar/ } \\
\text { Sludge, } \\
\text { mL }\end{array}$ & Al & $\mathrm{Fe}$ & $\mathbf{U}$ & $\mathbf{U}_{\text {metal }}^{\text {(a) }}$ & \\
\hline FE-5 & KE Weasel Pit and South Loadout Pit & $500 / 260$ & 2.66 & 30.6 & 5.32 & 0.05 & 1.66 \\
\hline $\mathrm{KC}-2 / 3$ & $\begin{array}{l}\text { Consolidated samples from fuel storage canisters } \\
\text { with moderate and highly damaged fuel }\end{array}$ & $1000 / 425$ & 5.16 & 1.84 & 59.0 & 3.22 & 2.03 \\
\hline $\begin{array}{l}\text { KE Floc } \\
\text { Comp }\end{array}$ & $\begin{array}{l}\text { Flocculated composite of KC-4 M250, KC-5, FE-5, } \\
\text { KC Can Comp }\end{array}$ & $500 / 260$ & 7.70 & 24.2 & 10.3 & 0.02 & 1.25 \\
\hline KC-6 & $\begin{array}{l}\text { Consolidated sample from floor area in west bay } \\
\text { known to be high in OIER }\end{array}$ & $250 / 140$ & $1.87^{(\mathrm{b})}$ & $1.51^{(\mathrm{b})}$ & $0.314^{(\mathrm{b})}$ & $<0.01$ & 1.31 \\
\hline \multicolumn{8}{|c|}{$\begin{array}{l}\text { (a) Estimated uranium metal concentration based on xenon fission product gas release analyses of constituent sludges (Bryan et al. } \\
2004 \text { for FE-5 and KC-6, Delegard et al. } 2000 \text { for KC-2/3, and both Bryan et al. } 2004 \text { and Schmidt et al. } 2004 \text { for KE Floc Comp) } \\
\text { (b) No analytical data are available for KC-6, which contains high concentrations of organic ion exchange resin beads. Data are } \\
\text { from the similar sample KES-H-08. The acid-insoluble residue concentration for KES-H-08 is } 97.3 \mathrm{wt} \% \text { on a dry basis. } \\
\text { The acid insoluble residue is OIER and mordenite inorganic exchange media (Schmidt et al. 1999). }\end{array}$} \\
\hline
\end{tabular}

Nine additional tests with greater amounts of added uranium metal ( 0.025 to $1.29 \mathrm{wt} \%$, settled basis) as well as two blank tests (no added uranium metal) were run for sludge KE Floc Comp according to the sequence shown in Figure 2.1. In these later tests, two 2-hour $/ 80^{\circ} \mathrm{C}$ contacts with $\mathrm{Na}_{2} \mathrm{SO}_{4} / \mathrm{H}_{3} \mathrm{PO}_{4}$ again were used with intermittent vortex mixing.

As part of the testing, spectrophotometric analyses of the $\mathrm{Na}_{2} \mathrm{SO}_{4} / \mathrm{H}_{3} \mathrm{PO}_{4}$ digestion solution from the various genuine sludges were completed to identify the oxidation states of the dissolved uranium. 
Table 6.2. Chemical and Radiochemical Compositions of Sludge Used in Selective Dissolution Tests

\begin{tabular}{|c|c|c|c|c|}
\hline Sludge & FE-5 & KC-2/3 & KC-6 ${ }^{(\mathbf{a})}$ & KE Floc Comp ${ }^{(b)}$ \\
\hline \multicolumn{5}{|l|}{ Dry Basis } \\
\hline Element & \multicolumn{4}{|c|}{ Concentration, Wt\% } \\
\hline $\mathrm{Al}$ & 2.66 & 5.16 & 1.87 & 7.70 \\
\hline $\mathrm{Ca}$ & 1.2 & 0.134 & 1.22 & 0.945 \\
\hline $\mathrm{Fe}$ & 30.6 & 1.84 & 1.51 & 24.2 \\
\hline $\mathrm{Mg}$ & 0.146 & 0.0462 & 0.225 & 0.230 \\
\hline $\mathrm{Na}$ & $\mathrm{BDL}^{(\mathrm{c})}$ & 0.24 & 3.26 & 0.365 \\
\hline $\mathrm{Si}$ & 0.330 & 0.752 & $\mathrm{NR}^{(\mathrm{d})}$ & 3.57 \\
\hline $\mathrm{U}^{(\mathrm{e})}$ & 5.32 & 59.0 & 0.314 & 10.3 \\
\hline Compound $^{(\mathrm{f})}$ & 77.1 & 94.8 & 16.9 & 92.6 \\
\hline Radionuclide & \multicolumn{4}{|c|}{ Concentration, $\mu \mathrm{Ci} / \mathrm{g}$} \\
\hline${ }^{60} \mathrm{Co}$ & 0.875 & 0.441 & 0.185 & 1.02 \\
\hline${ }^{137} \mathrm{Cs}$ & 170 & 860 & 144 & 783 \\
\hline${ }^{154} \mathrm{Eu}$ & 0.985 & 8.14 & BDL & 1.68 \\
\hline${ }^{238} \mathrm{Pu}$ & 2.06 & 16.2 & 0.0618 & 3.22 \\
\hline${ }^{239 / 240} \mathrm{Pu}$ & 13.1 & 114 & 0.403 & 23.9 \\
\hline${ }^{241} \mathrm{Am}$ & 10.4 & 90.5 & 0.397 & 18.9 \\
\hline \multicolumn{5}{|l|}{ Settled Sludge Basis } \\
\hline Element / $\mathrm{H}_{2} \mathrm{O}$ & \multicolumn{4}{|c|}{ Concentration, $\mathrm{Wt}^{\circ}{ }^{(7)}$} \\
\hline $\mathrm{Al}$ & 1.56 & 3.04 & 0.802 & 2.53 \\
\hline $\mathrm{Ca}$ & 0.704 & 0.0791 & 0.523 & 0.310 \\
\hline $\mathrm{Fe}$ & 18.0 & 1.09 & 0.648 & 7.92 \\
\hline $\mathrm{Mg}$ & 0.0857 & 0.0273 & 0.0965 & 0.0755 \\
\hline $\mathrm{Na}$ & $\mathrm{BDL}$ & 0.142 & 1.40 & 0.120 \\
\hline $\mathrm{Si}$ & 0.194 & 0.444 & NR & 1.17 \\
\hline $\mathrm{U}$ & 3.12 & 34.8 & 0.135 & 3.37 \\
\hline $\mathrm{H}_{2} \mathrm{O}$ & 41.3 & 41.0 & 57.1 & 67.2 \\
\hline \multicolumn{5}{|c|}{ Concentration, $\mu \mathrm{Ci} / \mathrm{g}^{(\mathrm{g})}$} \\
\hline${ }^{60} \mathrm{Co}$ & 0.514 & 0.260 & 0.0794 & 0.334 \\
\hline${ }^{137} \mathrm{Cs}$ & 100 & 507 & 61.8 & 257 \\
\hline${ }^{154} \mathrm{Eu}$ & 0.578 & 4.80 & $\mathrm{BDL}$ & 0.552 \\
\hline${ }^{238} \mathrm{Pu}$ & 1.21 & 9.56 & 0.0265 & 1.06 \\
\hline${ }^{239 / 240} \mathrm{Pu}$ & 7.69 & 67.3 & 0.173 & 7.84 \\
\hline${ }^{241} \mathrm{Am}$ & 6.10 & 53.4 & 0.170 & 6.20 \\
\hline Reference $^{(\mathrm{h})}$ & $\mathrm{a}$ & $\mathrm{a}$ & $\mathrm{a}, \mathrm{b}, \mathrm{c}$ & $\mathrm{a}, \mathrm{d}$ \\
\hline \multicolumn{5}{|c|}{$\begin{array}{l}\text { (a) No analytical data are available for KC-6, which contains high concentrations of organic ion exchange resin beads. Data are from the } \\
\text { similar sample KES-H-08. The acid-insoluble residue concentration is } 9.73 \times 10^{5} \mu \mathrm{g} / \mathrm{g} \text { (on a dry basis) for KES-H- } 08 \text {. }\end{array}$} \\
\hline \multirow{4}{*}{\multicolumn{5}{|c|}{$\begin{array}{ll}\text { (b) } & \text { KE Floc Comp (floccula } \\
& \text { KC Canister Composite } \\
& \text { (except KC Canister Cor } \\
\text { (c) } & \text { BDL means below detec } \\
\text { (d) NR means not reported. } \\
\text { (e) Uranium concentrations } \\
\text { values were not availabl }\end{array}$}} \\
\hline & & & & \\
\hline & & & & \\
\hline & & & & \\
\hline \multicolumn{5}{|c|}{$\begin{array}{l}\text { (f) Based on assignment of the e } \\
\mathrm{Al}(\mathrm{OH})_{3}, \mathrm{CaCO}_{3} \text {, and } \mathrm{SiO}_{2} \text { ha } \\
\text { the likely state of the wet iron } \\
\text { by X-ray diffraction [XRD]). } \\
\text { phase identifiable by XRD. }\end{array}$} \\
\hline
\end{tabular}


Table 6.2. Chemical and Radiochemical Compositions of Sludge Used in Selective Dissolution Tests

\begin{tabular}{|c|c|c|c|c|c|}
\hline & Sludge & FE-5 & KC-2/3 & KC-6 ${ }^{(\mathbf{a})}$ & KE Floc Comp ${ }^{(b)}$ \\
\hline (g) & \multicolumn{5}{|c|}{$\begin{array}{l}\text { uranium phases most frequently observed in sludge (see Schmidt and Delegard 2003). The material balance shortfall for KC-6 (KES-H- } \\
08 \text { ) is because of the presence of OIER, which is composed largely of organic polymers, and mordenite (inorganic ion exchanger), both of } \\
\text { which do not dissolve in the acid digestion done for this sample. All other sample analyses are based on fusion digests. } \\
\text { Settled sludge analyses are calculated based on the water concentrations of the respective sludges. Note that drying and wetting in storage } \\
\text { and during sample maintenance will alter these values and that water-concentration values should be determined upon use to re-establish } \\
\text { the component concentrations. }\end{array}$} \\
\hline
\end{tabular}

(a) RB Baker, and TL Welsh. 2001. "Laboratory Data from the Consolidated and Single Pull Core Sludge Sampling Campaign.” Internal FH Memo, 01-SNF/RBB-004, May 10, 2001, Spent Nuclear Fuel Project, Fluor Hanford, Richland, WA. 


\subsection{Results for Uranium Metal Analysis in K Basin Sludge}

Cemented agglomerates were observed when the $\mathrm{Na}_{2} \mathrm{SO}_{4}$-bearing $\mathrm{H}_{3} \mathrm{PO}_{4}$ was added to $\mathrm{KC}-2 / 3$ canister sludge that is rich in uranium oxides. The solids, suspected to be U(VI) phosphates, yielded somewhat to shaking and crushing to improve the acid-sludge contact in the initial set of tests with this sludge. Despite these measures, however, undissolved oxidized uranium evidently remained. This was shown when the solids dissolved quickly when cell-temperature $10 \mathrm{M} \mathrm{HNO}_{3}$ was added to the heel solids. A bright yellow color indicating dissolved uranium(VI) was observed. The uranium concentration analyses of the sixth and seventh $0.5-\mathrm{M} \mathrm{HNO}_{3}$ rinses of the $\mathrm{KC}-2 / 3$ sludge also were atypically high.

The rapid and intense yellow color developed in the $10 \mathrm{M} \mathrm{HNO}_{3}$ contact, and the high-rinse values suggested that the source was not the added uranium metal. Preliminary KPA confirmed that the heel contained uranium concentrations well in excess of the amounts of uranium metal added. Because of these observations of undissolved sludge, tests with $\mathrm{KC}-2 / 3$ were repeated under approved test instructions using more aggressive agitation supplied by a vortex mixer. A second $\mathrm{Na}_{2} \mathrm{SO}_{4} / \mathrm{H}_{3} \mathrm{PO}_{4}$ contact also was implemented to improve sludge solids dissolution. ${ }^{(\mathrm{e})}$ Because these additional measures were found to be effective in dissolving the oxidized uranium phases, they have been adopted into the standard selective dissolution procedure as shown in Figure 2.1.

As part of the testing, spectrophotometric analyses of the $\mathrm{Na}_{2} \mathrm{SO}_{4} / \mathrm{H}_{3} \mathrm{PO}_{4}$ digestion solution from the various genuine sludges were completed to identify the oxidation states of the dissolved uranium. The analyses showed the presence of dissolved iron(III) and uranium(IV) and (VI).

A significant interference at low wavelengths also was observed. Filtration and centrifugation did not remove the interference. A spectrum of the solution generated by treating Hanford blow sand with $\mathrm{Na}_{2} \mathrm{SO}_{4} / \mathrm{H}_{3} \mathrm{PO}_{4}$ showed the same steeply increasing absorbance as the wavelength decreased. These findings indicate that the low wavelength interference may have been caused by light scattering by colloidal silica or by organic materials present in the blow sand. A sample of basalt rock (which would contain no organic material) was crushed and then treated with hot $\mathrm{Na}_{2} \mathrm{SO}_{4} / \mathrm{H}_{3} \mathrm{PO}_{4}$. The spectra of the blow sand and the crushed basalt (Figure 7.1) both showed the low wavelength interference, indicating that silica was responsible for at least part of the interference. Each spectrum also showed a broad peak at about $405 \mathrm{~nm}$ that is attributed to Fe(III) based on measurements of dissolved ferrihydrite. The attribution of the interference to silica particles is strengthened by knowledge that silica sol is made by treating soluble silicates with acid and that at a 400-nm wavelength, light absorbance increases with sol concentration and with sol particle size (Iler 1979, pp. 331-332 and 348-349). The sols have $~ 10-$ to 60nm particle diameters.

(e) CH Delegard. 2008. "Uranium Metal Analysis Testing for K East Basin Canister Sludge," 53451-TI08, Pacific Northwest National Laboratory, Richland, WA. 


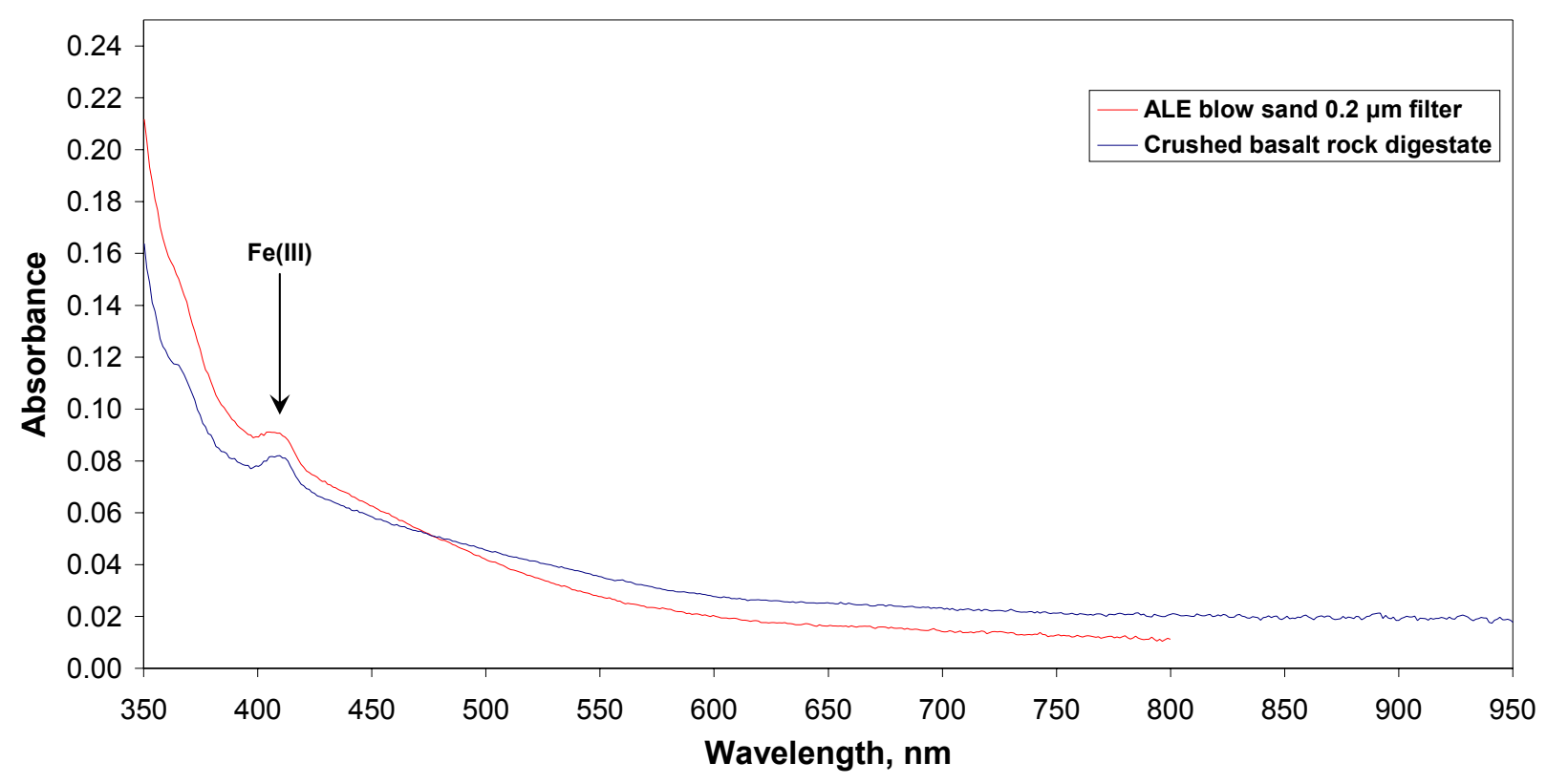

Figure 7.1. Absorbance Spectra of Solutions Produced by $\mathrm{Na}_{2} \mathrm{SO}_{4} / \mathrm{H}_{3} \mathrm{PO}_{4}$ Digestion of Blow Sand and Crushed Basalt

Figure 7.2 shows spectra for samples FE-5, which has a high interference at low wavelengths, which is likely due to silica sols, and sample KC-2/3, which contains relatively high uranium concentrations and had to be diluted by a factor of five to be measured accurately. Both spectra show peaks characteristic of $\mathrm{U}(\mathrm{IV})$, between 600 and $700 \mathrm{~nm}$, and of U(VI), the multiplet centered at $\sim 420 \mathrm{~nm}$. The FE-5 sample also shows significant broad absorbance near $400 \mathrm{~nm}$, which is indicative of $\mathrm{Fe}(\mathrm{III})$.

The sludge sample spectra were interpreted using silica background correction to show that uranium(IV) ranged from only about 2.3 to $20 \%$ of the total dissolved uranium (Table 7.1 ), confirming that significant uraninite $\left(\mathrm{UO}_{2}, \mathrm{U}_{4} \mathrm{O}_{9}, \mathrm{U}_{3} \mathrm{O}_{7}\right)$ oxidation has occurred during the hot cell storage of sludge for the past 9 to 10 years. The plutonium concentration in the $\mathrm{KE}$ canister sludge $(\mathrm{KC}-2 / 3)$ also was measured based on plutonium spectral data obtained in $\mathrm{Na}_{2} \mathrm{SO}_{4}$-bearing $\mathrm{H}_{3} \mathrm{PO}_{4}$ and its peak intensity relative to uranium. The plutonium concentration measured by spectrophotometry was fully consistent with that expected based on prior sludge analyses, attaining 95\% recovery of the known value. Comparison of the data for the $\mathrm{KE}$ Floc Comp and the KE Floc Comp and KC-6 tests show that the presence of IXM (in KC-6) affects the relative amounts of $\mathrm{U}(\mathrm{IV})$ and $\mathrm{U}(\mathrm{VI})$ in the $\mathrm{Na}_{2} \mathrm{SO}_{4} / \mathrm{H}_{3} \mathrm{PO}_{4}$ solution by the apparent selective absorption of U(VI). 


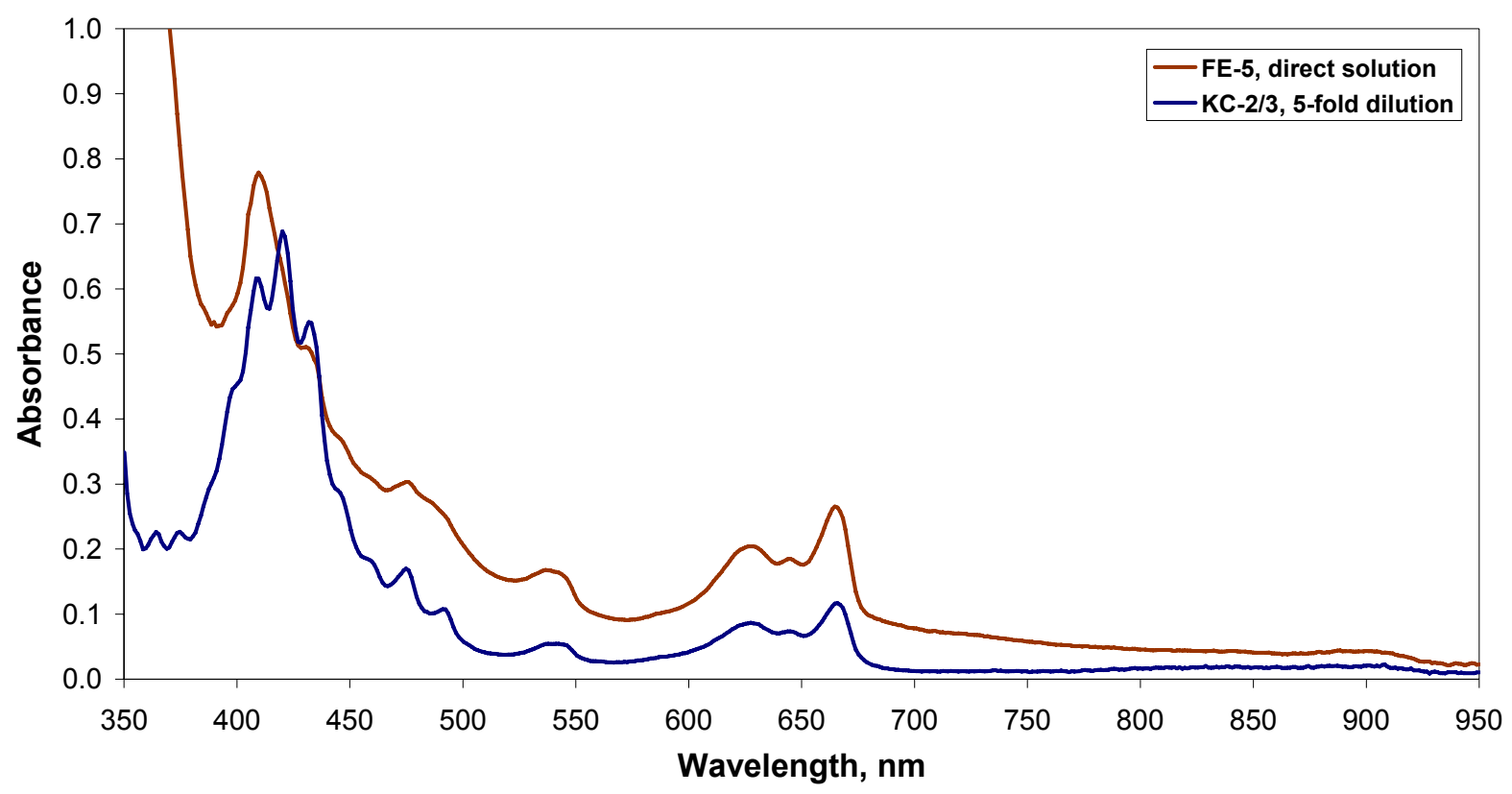

Figure 7.2. Spectra of Solutions Produced by $\mathrm{Na}_{2} \mathrm{SO}_{4} / \mathrm{H}_{3} \mathrm{PO}_{4}$ Digestion of Sludge Samples FE-5 and $\mathrm{KC}-2 / 3$

Table 7.1. Uranium(IV) Percentages in Sludge Samples Dissolved in $\mathrm{Na}_{2} \mathrm{SO}_{4} / \mathrm{H}_{3} \mathrm{PO}_{4}$

\begin{tabular}{|l|c|}
\hline \multicolumn{1}{|c|}{ Sludge } & $\begin{array}{c}\text { U(IV), \% of Total } \\
\text { Dissolved Uranium }\end{array}$ \\
\hline FE-5 & 20.0 \\
\hline KC-2/3 & $3.9,3.7,4.6 ; 4.1$ (avg.) \\
\hline KE Floc Comp & 2.3 \\
\hline KE Floc Comp \& KC-6 & 10.8 \\
\hline
\end{tabular}

Results of the uranium solution analyses in the sixth and seventh $0.5-\mathrm{M} \mathrm{HNO}_{3}$ rinses and in the $10-\mathrm{M}$ $\mathrm{HNO}_{3}$ dissolution step are presented in Table 7.2. The results from the first set of tests for $\mathrm{KC}-2 / 3$ are omitted from Table 7.2 because of the known incomplete oxidized uranium dissolution in the single $\mathrm{Na}_{2} \mathrm{SO}_{4} / \mathrm{H}_{3} \mathrm{PO}_{4}$ step. The concentrations in the sixth and seventh rinses for the original $\mathrm{KC}-2 / 3$ test were approximately 100 to 1000 times greater than those reported in Table 7.2 for the re-run test.

The $0.5-\mathrm{M} \mathrm{HNO}_{3}$ rinse concentrations ranged from about 0.25 to $10 \mathrm{ppm}$ under conditions in which the initial $\mathrm{Na}_{2} \mathrm{SO}_{4} / \mathrm{H}_{3} \mathrm{PO}_{4}$ solution would have contained as much as $12,000 \mathrm{ppm}$ of uranium. The uranium concentrations in the $10-\mathrm{M} \mathrm{HNO}_{3}$ blank test solutions for the four different sludges were about 1 to 25 times higher than the rinse concentrations. This suggests that the higher acid concentration often led to enhanced uranium dissolution or displacement from the sludge heel. The lowest uranium concentrations observed in the 10- $\mathrm{M} \mathrm{HNO}_{3}$ blank test digestions occurred for the composite sludge (KE Floc Comp) selected to emulate the containerized sludge. The same sludge, but blended with the IXM-rich KC-6 sludge, had the second lowest uranium concentration. 
Table 7.2. Uranium Concentrations in 0.5 -M Nitric Acid Rinses and in 10 -M Nitric Acid Digestions

\begin{tabular}{|c|c|c|c|c|c|c|}
\hline \multirow{3}{*}{$\begin{array}{l}\text { Sludge Type } \\
\text { Represented }\end{array}$} & \multirow{3}{*}{$\begin{array}{c}\text { Sludge } \\
\text { Used }\end{array}$} & \multirow{3}{*}{\begin{tabular}{|c|} 
Number of \\
$\mathrm{Na}_{2} \mathrm{SO}_{4} / \mathrm{H}_{3} \mathrm{PO}_{4}$ \\
Contacts \\
\end{tabular}} & \multirow[b]{3}{*}{ Sample } & \multicolumn{3}{|c|}{ 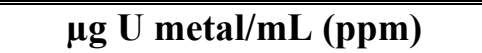 } \\
\hline & & & & \multicolumn{2}{|c|}{$0.5 \mathrm{M} \mathrm{HNO}_{3}$} & \multirow{2}{*}{$\begin{array}{c}10 \mathrm{M} \\
\mathrm{HNO}_{3}\end{array}$} \\
\hline & & & & $6^{\text {th }}$ Rinse & $7^{\text {th }}$ Rinse & \\
\hline \multirow{3}{*}{ Pit } & \multirow{3}{*}{ FE-5 } & \multirow{3}{*}{1} & Blank-no U metal & 8.84 & 9.69 & 44.8 \\
\hline & & & With U metal-Test 1 & 5.27 & 4.12 & 54.8 \\
\hline & & & With U metal-Test 2 & 4.21 & 4.59 & 59.9 \\
\hline \multirow{3}{*}{ Settler } & \multirow{3}{*}{$\mathrm{KC}-2 / 3$} & \multirow{3}{*}{2} & Blank-no U metal & 2.23 & 0.854 & 17.4 \\
\hline & & & With U metal-Test 1 & 3.85 & 6.38 & 22.0 \\
\hline & & & With U metal-Test 2 & 1.26 & 0.717 & 157 \\
\hline \multirow{3}{*}{ Containerized } & \multirow{3}{*}{$\begin{array}{l}\text { KE Floc } \\
\text { Comp }\end{array}$} & \multirow{3}{*}{1} & Blank-no U metal & 1.12 & 3.69 & 3.90 \\
\hline & & & With U metal-Test 1 & 1.65 & 4.17 & 29.6 \\
\hline & & & With U metal-Test 2 & 3.87 & 8.92 & 47.8 \\
\hline \multirow{3}{*}{$\begin{array}{l}\text { Containerized } \\
\text { with IXM }\end{array}$} & \multirow{3}{*}{$\begin{array}{l}\text { KE Floc } \\
\text { Comp \& } \\
\text { KC-6 }\end{array}$} & \multirow{3}{*}{1} & Blank-no U metal & 2.27 & 3.94 & 6.59 \\
\hline & & & With U metal_-Test 1 & 1.31 & 1.91 & 44.4 \\
\hline & & & With U metal-Test 2 & 2.04 & 1.66 & 34.5 \\
\hline \multirow{11}{*}{ Containerized } & \multirow{11}{*}{$\begin{array}{l}\text { KE Floc } \\
\text { Comp }\end{array}$} & \multirow{11}{*}{2} & Blank-no U metal-1 & 0.254 & 0.468 & 6.45 \\
\hline & & & Blank-no U metal-2 & 2.53 & 1.99 & 32.6 \\
\hline & & & With U metal-Test 1 & 0.497 & 0.369 & 142 \\
\hline & & & With U metal-Test 2 & 1.82 & 1.23 & 289 \\
\hline & & & With U metal-Test 3 & 2.54 & 0.664 & 331 \\
\hline & & & With U metal-Test 4 & 0.412 & 4.68 & 691 \\
\hline & & & With U metal-Test 5 & 1.23 & 1.41 & 456 \\
\hline & & & With U metal-Test 6 & 1.24 & 1.82 & 1300 \\
\hline & & & With U metal-Test 7 & 0.901 & 0.558 & 2890 \\
\hline & & & With U metal-Test 8 & 0.748 & 1.25 & 6840 \\
\hline & & & With U metal-Test 9 & 1.43 & 2.89 & 7750 \\
\hline
\end{tabular}

The uranium metal analysis recovery data for the tests with uranium metal spiked and unspiked K Basin sludge are shown in Table 7.3 and Figure 7.3.

The uranium concentrations found in the blank heels remaining after the $\mathrm{Na}_{2} \mathrm{SO}_{4} / \mathrm{H}_{3} \mathrm{PO}_{4}$ dissolution step and dilute $\mathrm{HNO}_{3}$ rinses range from 0.0010 to $0.0099 \mathrm{wt} \% \mathrm{U}$. This indicates that no appreciable amounts of uranium metal remained in any of the tested sludges, including the $\mathrm{KC}-2 / 3$ sludge, which originally contained about $3.2 \mathrm{wt} \%$ uranium when analyzed by gas-generation techniques in 2000 .

The amounts of uranium metal added in the initial tests with the FE-5, KE Floc Comp, and KE Floc Comp with KC-6 sludge range from 0.0064 to $0.0085 \mathrm{wt} \%$ and thus are only about 2 to 3 times the $0.0037-\mathrm{wt} \%$ uranium metal average lower detection limit based on the blank analyses. The amounts of uranium metal added to the tests with the $\mathrm{KC}-2 / 3$ sludge were 0.0121 and $0.0146 \mathrm{wt} \%$, about 4 times the average lower detection limit. The uranium metal recoveries for seven of eight of these tests range from 106 to $179 \%$ with the high recoveries at least partly due to the high relative contributions of the analytical 
background uranium compared with the small amounts of added uranium metal. The uranium metal concentration for the eighth test, Test 1 of the $\mathrm{KC}-2 / 3$ determination, was only $0.0030 \mathrm{wt} \%$, or $25 \%$ of the amount added. Because of the low recovery, it is likely that the transfer of the miniscule uranium metal bead to the sludge did not occur for this test.

Table 7.3. Uranium Metal Analysis Results in Uranium Metal Unspiked and Spiked K Basin Sludge

\begin{tabular}{|c|c|c|c|c|c|c|c|c|}
\hline \multirow[b]{2}{*}{$\begin{array}{l}\text { Sludge Type } \\
\text { Represented }\end{array}$} & \multirow[b]{2}{*}{$\begin{array}{c}\text { Sludge } \\
\text { Used }\end{array}$} & \multirow[b]{2}{*}{$\begin{array}{c}\text { Number of } \\
\mathrm{Na}_{2} \mathrm{SO}_{4} / \mathrm{H}_{3} \mathrm{PO}_{4} \\
\text { Contacts }\end{array}$} & \multirow[b]{2}{*}{ Sample } & \multicolumn{4}{|c|}{$\left[\mathbf{U}_{\text {metal }}\right], \mathbf{w t} \%$} & \multirow[b]{2}{*}{$\begin{array}{c}\text { Recovery, } \\
\%\end{array}$} \\
\hline & & & & \multicolumn{2}{|c|}{ Added } & Found & \begin{tabular}{|c|} 
Diff. \\
(Found- \\
Added)
\end{tabular} & \\
\hline \multirow{3}{*}{ Pit } & \multirow{3}{*}{ FE-5 } & \multirow{3}{*}{1} & Blank-no U metal & \multicolumn{2}{|c|}{0.00000} & 0.00994 & 0.00994 & NA \\
\hline & & & With U metal-1 & \multicolumn{2}{|c|}{0.00679} & 0.0107 & 0.00392 & 157.7 \\
\hline & & & With U metal—2 & \multicolumn{2}{|c|}{0.00670} & 0.0113 & 0.00458 & 168.2 \\
\hline \multirow{3}{*}{ Settler } & \multirow{3}{*}{$\mathrm{KC}-2 / 3$} & \multirow{3}{*}{2} & Blank-no U metal & \multicolumn{2}{|c|}{0.00000} & 0.00286 & 0.00286 & NA \\
\hline & & & With U metal-1 ${ }^{\text {(a) }}$ & \multicolumn{2}{|c|}{0.0121} & 0.00300 & -0.00907 & 24.8 \\
\hline & & & With U metal—2 & \multicolumn{2}{|c|}{0.0146} & 0.0262 & 0.0116 & 179.3 \\
\hline \multirow{3}{*}{ Containerized } & \multirow{3}{*}{$\begin{array}{l}\text { KE Floc } \\
\text { Comp }\end{array} \mid$} & \multirow{3}{*}{1} & Blank-no U metal & \multicolumn{2}{|c|}{0.00000} & 0.00096 & 0.00096 & NA \\
\hline & & & With U metal-1 & \multicolumn{2}{|c|}{0.00490} & 0.00783 & 0.00293 & 159.8 \\
\hline & & & With U metal—2 & \multicolumn{2}{|c|}{0.00941} & 0.0132 & 0.00382 & 140.6 \\
\hline \multirow{3}{*}{$\begin{array}{l}\text { Containerized } \\
\text { with IXM }\end{array}$} & \multirow{3}{*}{$\begin{array}{l}\text { KE Floc } \\
\text { Comp } \\
\& \text { KC-6 }\end{array}$} & \multirow{3}{*}{1} & Blank-no U metal & \multicolumn{2}{|c|}{0.00000} & 0.00140 & 0.00140 & NA \\
\hline & & & With U metal-1 & 0.00 & 777 & 0.0118 & 0.00404 & 152.0 \\
\hline & & & With U metal-2 & 0.00 & 808 & 0.00860 & 0.00052 & 106.4 \\
\hline & & & Blank-no U metal-1 & 0.00 & 000 & 0.00141 & 0.00141 & NA \\
\hline & & & Blank-no U metal-2 & 0.00 & 000 & 0.00589 & 0.00589 & NA \\
\hline & & & With U metal-1 & 0.02 & & 0.0247 & -0.00037 & 98.5 \\
\hline & & & With U metal-2 & 0.05 & & 0.0602 & \begin{tabular}{|l|}
0.00109 \\
\end{tabular} & 101.8 \\
\hline & & & With U metal-3 & 0.06 & & 0.0641 & 0.00236 & 103.8 \\
\hline Containerized & KE Floc & 2 & With U metal-4 & 0.13 & & 0.135 & -0.00352 & 97.5 \\
\hline & & & With U metal-5 & 0.08 & & 0.0830 & \begin{tabular}{|l|}
0.00171 \\
\end{tabular} & 102.1 \\
\hline & & & With U metal-6 & 0.27 & & 0.280 & \begin{tabular}{|l|}
0.00467 \\
\end{tabular} & 101.7 \\
\hline & & & With U metal-7 & 0.52 & & 0.517 & -0.00402 & 99.2 \\
\hline & & & With U metal-8 & 1.21 & & 1.166 & -0.0443 & 96.3 \\
\hline & & & With U metal—9 & 1.29 & & 1.207 & -0.0836 & 93.5 \\
\hline & & & Blank only. & & & Average & 0.0037 & \\
\hline & & & & & Stan & idard Dev. & 0.0035 & \\
\hline 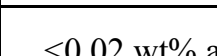 & added urar & nium metal (KC-2/ & 13 Test 1 excluded $) \cdot 13$ t & & & Average & 0.0041 & \\
\hline$<0.02 \mathrm{wt} \% \mathrm{a}$ & added uran & nium metal (KC-2/ & /3 lest 1 excluded); 13 te & & Stan & dard Dev. & 0.0033 & \\
\hline$<1, w t^{0}$ & $a d d$ & nium metal $(\mathrm{KC}$ & 12 Toct 1 ouludod). ? & & & Average & 0.0028 & \\
\hline$<$ & add & nium metal (KC-2 & xclu & & $\overline{\text { Stan }}$ & idard Dev. & 0.0037 & \\
\hline
\end{tabular}




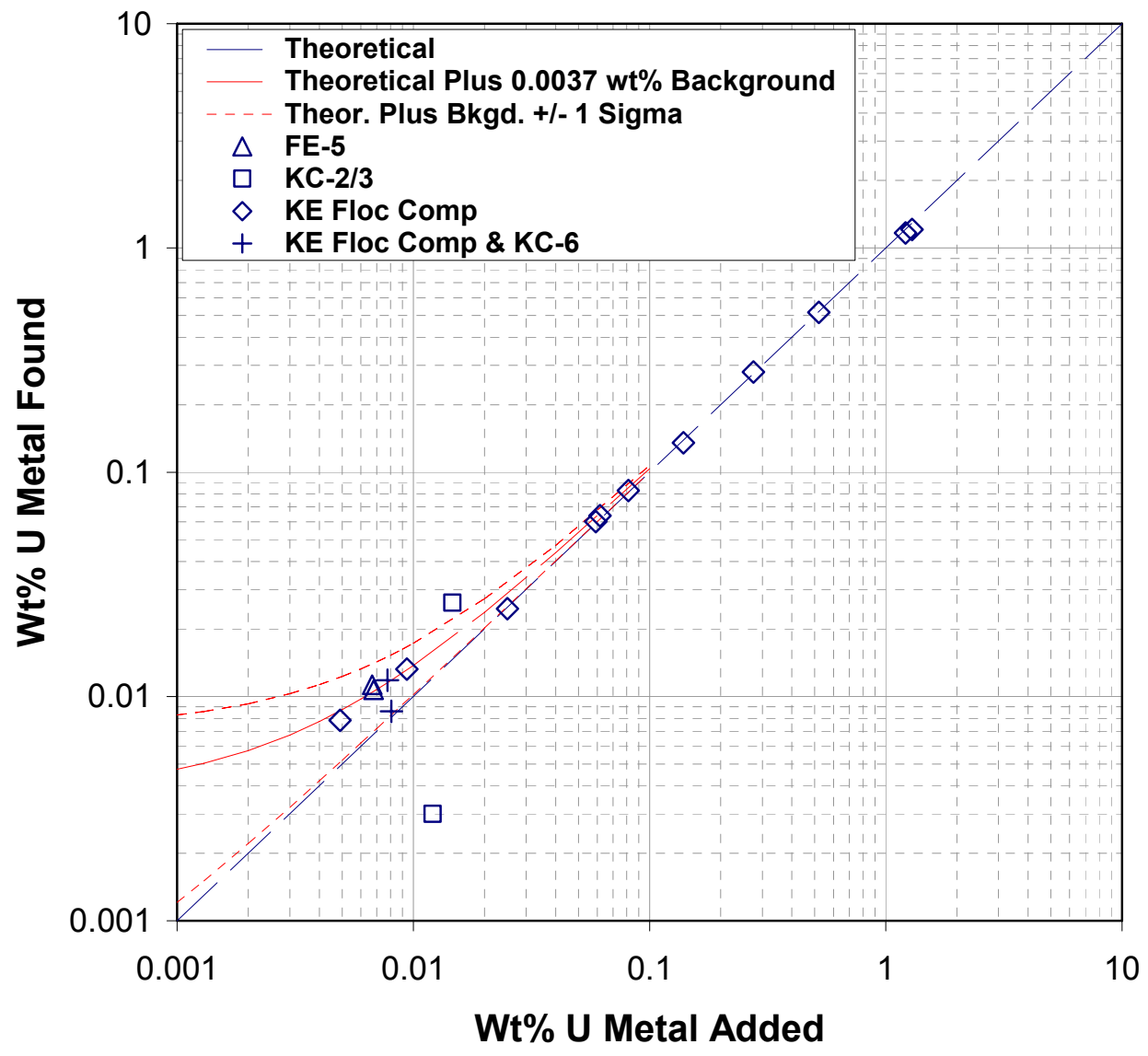

Figure 7.3. Uranium Metal Analysis Recoveries in Spiked and Unspiked K Basin Sludge

The average background for the six blank tests is $0.0037 \pm 0.0035 \mathrm{wt} \%$ (at one standard deviation). This level of background concentration appears to be the result of variable traces of residual oxidized uranium remaining in the insoluble residue after the $\mathrm{Na}_{2} \mathrm{SO}_{4} / \mathrm{H}_{3} \mathrm{PO}_{4}$ strike(s) and the dilute $\mathrm{HNO}_{3}$ rinses and may also include uranium displaced from solids surfaces by the $10 \mathrm{M} \mathrm{HNO}_{3}$. The uranium quantities leached from the blank heels with $10 \mathrm{M} \mathrm{HNO}_{3}$ are lower, on average, than the 0.0065 - and 0.0103 -wt\% values observed in tests with the simulated sludge (Table 5.2), but the differences are not statistically significant.

Because many of the tests were run with small amounts of added uranium metal, the average background also may be calculated as the difference between the amount of uranium metal found by analysis and the amount of uranium added. The differences between the as-found and added uranium concentrations are shown in Table 7.3. The average background calculated from the differences between the as-found and added uranium concentrations for the 13 tests run below $0.02 \mathrm{wt} \%$ added uranium (including the blank tests but excluding the anomalous first test of $\mathrm{KC}-2 / 3$ ) is $0.0041 \pm 0.0033 \mathrm{wt} \%$. These values are comparable to the values found for the six blank tests alone. Even for the 20 test runs below $1 \mathrm{wt} \%$ added uranium (again excluding the single outlying $\mathrm{KC}-2 / 3$ result), the average background is $0.0028 \pm 0.0037 \mathrm{wt} \%$. Based on these findings, the nominal background concentration is estimated to be $\sim 0.004 \mathrm{wt} \%$. 
As shown in Table 7.3 and Figure 7.3, aside from Test 1 of the $\mathrm{KC}-2 / 3$ experiment, the uranium metal concentrations found by the selective dissolution technique correspond well with the concentrations of added uranium metal if the average analytical background concentration is included. However, at uranium metal concentrations lower than about $0.01 \mathrm{wt} \%$, the average background uranium concentration of $\sim 0.004 \mathrm{wt} \%$ becomes an increasingly significant contributor to the total analyzed uranium concentration. The uranium metal recoveries for tests above $0.02 \mathrm{wt} \%$ uranium (Tests 1 through 9 for $\mathrm{KE}$ Floc Comp having two $\mathrm{Na}_{2} \mathrm{SO}_{4} / \mathrm{H}_{3} \mathrm{PO}_{4}$ contacts) average $99.4 \mathrm{wt} \%$ with a standard deviation of $3.3 \mathrm{wt} \%$. 


\subsection{Uranium Metal Concentrations in Sludge Compared with Analysis Targets}

The uranium metal concentration testing with unspiked simulated sludge and KE Basin sludge show analytical detection limits of $\sim 0.004 \mathrm{wt} \%$. This value is 8.5 times lower than the Safety Basis uranium metal content for KE North Loadout Pit (NLOP) sludge. The KE NLOP sludge has been successfully packaged (as contact handled transuranic waste) for disposal to WIPP. The $0.004-\mathrm{wt} \%$ detection limit is also a factor of 65 less than the current design basis uranium metal content for KE Floor sludge. Thus, deploying this method to characterize new sludge samples affords the Sludge Treatment Project the potential to measure a significantly lower uranium metal content than that given in current design/safety basis documents.

Further consideration of the target detection and quantitation limits is worthwhile. Some of the considerations are based on the uranium metal concentrations known or projected in various $\mathrm{K}$ Basin sludge streams as shown in Table 8.1.

Table 8.1. Uranium Metal Concentrations in Sludge and Considerations for Measurement Detection Limit

\begin{tabular}{|c|c|c|}
\hline Stream & $\begin{array}{c}{\left[\mathrm{U}_{\text {Metal }}\right], \mathrm{wt} \%} \\
\text { (settled sludge } \\
\text { basis) } \\
\end{array}$ & Reference/Assumptions \\
\hline \multicolumn{3}{|l|}{ Design Bases } \\
\hline KE NLOP Design Basis & 0.0057 & \multirow{2}{*}{$\begin{array}{l}\text { Schmidt 2006. Note that } \mathrm{H}_{2} \text { generation from KE } \\
\text { NLOP (Safety Basis) is not a handling, shipping, or } \\
\text { storage issue for grouted KE NLOP sludge (at } \\
\sim 20 \text { liters of sludge per drum). }\end{array}$} \\
\hline KE NLOP Safety Basis & 0.034 & \\
\hline KE Floor Design Basis & 0.26 & \multirow{4}{*}{ Schmidt 2006.} \\
\hline KE Floor Safety Basis & 1.5 & \\
\hline KE Canister Design Basis & 2.1 & \\
\hline KE Canister Safety Basis & 5 & \\
\hline 93/7 Mix KE Floor/Can - Design & 0.45 & Calculation from KE Floor and Canister Design Basis. \\
\hline \multicolumn{3}{|c|}{ Sludge Analyses (via gas-generation testing) } \\
\hline Canister sludge, $\mathrm{KC}-2 / 3$ & 1.9 & Delegard et al. 2000 (meas'd. Oct. 1999-April 2000). \\
\hline Weasel Pit sludge, FE-5 & 0.027 & Bryan et al. 2004 (meas'd. July-Sept. 2000). \\
\hline \multicolumn{3}{|l|}{ Shipping Limit } \\
\hline $\begin{array}{l}\text { U metal limit in 55-gal drum in } \\
\text { RH-72B Cask, with } 96.4 \text { liters of } \\
\text { as-settled sludge. }\end{array}$ & $\sim 0.01$ & $\begin{array}{l}\text { Assumes: } 3 \text {-drum } 60 \text { day } \& 60^{\circ} \mathrm{C} \text { shipment }\left(3.65 \times 10^{-}\right. \\
\left.{ }^{8} \mathrm{~mol} / \mathrm{s}\right) ; 500-\mu \mathrm{m} \mathrm{U} \text { metal particles, no particle } \\
\text { consumption, no radiolysis, no matrix rate mitigation. }\end{array}$ \\
\hline \multicolumn{3}{|l|}{ Analytical Detection Limits } \\
\hline $\begin{array}{l}\text { Detection limit by xenon fission } \\
\text { product gas analysis based on Gas- } \\
\text { Generation II testing. }\end{array}$ & $\sim 0.005$ & $\begin{array}{l}\text { Bryan et al. } 2004 \text { (technique assumes knowledge of } \\
\text { the burn-up of source fuel). }\end{array}$ \\
\hline $\begin{array}{c}\text { Projected detection limit from initial } \\
\text { results of selective dissolution. }\end{array}$ & $\sim 0.004$ & $\begin{array}{l}\text { Based on testing of selective dissolution with actual } \\
\text { sludge samples (4 grams) spiked with U metal. }\end{array}$ \\
\hline
\end{tabular}


The uranium metal concentrations analyzed in sludge are compared in Table 8.1 with the projected $\sim 0.004 \mathrm{wt} \%$ uranium metal detection limit obtained for the present selective dissolution technique using about 4 grams of sludge sample and requiring about 7 to 14 days of preparation and analysis time and the $\sim 0.005 \mathrm{wt} \%$ uranium metal detection limit projected by xenon fission product gas release using about 20 grams of sludge and requiring about 2 months of preparation and analysis time. It is seen that the selective dissolution technique is about as sensitive and provides much more timely results than the alternative gas-generation-analysis technique. The gas-generation technique also must rely on estimates of uranium metal fuel exposure (typically, $2900 \mathrm{MWD} / \mathrm{MTU}$ [megawatt day/metric ton of uranium]) to be applied.

The target measurement limits to meet Sludge Treatment Project (STP) goals may also be affected by the following considerations related to grouting sludge and preparing it for shipment to, and disposal at, WIPP:

- It is unlikely that individual drums will be loaded with the 96-liter upper limit of as-settled sludge. A decreased waste loading will permit an increase in the allowable uranium metal concentration (uranium metal surface area).

- Smaller drums of lower capacity likely will be used. These drums then will be overpacked in 55-gallon drums. This will result in less sludge per shipment, increasing the allowable uranium metal concentration within the sludge.

- Some reaction of uranium metal will occur before, during, and after grout processing. The hydrogen generation rate is greatest at the beginning of the anoxic reaction time when the uranium metal surface area is greatest. Taking credit for the burn-out occurring before the $60^{\circ} \mathrm{C}$ 60-day shipping window will effectively double the allowable mass per drum as compared with assuming the uranium metal surface area remains constant.

- Some decrease in the uranium metal corrosion rate may occur because of the influence of the grout matrix. Prior testing has shown marginal rate decreases for certain grouted sludge (Delegard et al. 2004).

- A shorter shipping duration of 10 days instead of 60 days for transporting the RH-72B from Hanford to WIPP may be permitted. This shorter duration would effectively increase the allowable uranium metal content by a factor of 6 .

- The apportionment of hydrogen generation due to the uranium metal reaction with water and due to radiolysis will impact the allowable uranium metal content in the sludge during shipment. 


\subsection{Key Findings from Selective Dissolution Validation Testing}

The following conclusions and observations are based on the results of selective dissolution testing with complex K Basin sludge simulants containing uranium metal and actual sludge spiked with uranium metal:

- The uranium metal detection limit of $\sim 0.004 \mathrm{wt} \% \mathrm{U}$ metal (settled sludge basis) for selective dissolution is essentially equivalent to the $\sim 0.005 \mathrm{wt} \% \mathrm{U}$ metal detection limit achieved with testing based on xenon fission product gas release.

- The demonstrated method sensitivity appears sufficient to meet STP testing needs.

- The experimental results provide a sufficient technical basis for an approved routine analytical procedure for this approach.

- Uranium metal can be measured with $\sim 3$ to 5 grams of sample in 1 to 2 weeks with the selective dissolution method. For gas-generation testing, uranium metal measurements require about 20 grams of sample and can require in excess of 2 months.

- While both selective dissolution and gas-generation testing can provide data on uranium metal concentration in the sludge, gas-generation testing can also estimate the uranium metal particlesize distribution provided that sufficient metal concentrations exist in the sludge, and multiple gas analysis samples are taken. Information on uranium metal particle-size distribution can be obtained by selective dissolution methods if the sludge samples are first size classified (for example, by sieving).

- To counter uranium interference background from labware and reagents, the selective dissolution analysis uses plastic labware to minimize uranium contamination that is present at low levels in ordinary glass and uses high-purity $\mathrm{HNO}_{3}$ reagent prepared and held in plastic vessels.

- The quantification limit for selective dissolution can be affected by the ubiquitous uranium contamination in the hot cell and requires careful laboratory practices to minimize its influence.

- Beyond hot cell contamination, however, all selective dissolution preparations will contain a small quantity of oxidized uranium that is not removed from the sludge heel that remains after the $\mathrm{Na}_{2} \mathrm{SO}_{4} / \mathrm{H}_{3} \mathrm{PO}_{4}$ dissolution and subsequent serial $0.5 \mathrm{M} \mathrm{HNO}_{3}$ rinses. The residual uranium may arise because of incomplete oxidized uranium dissolution, but more typically is due to sorption on the heel solids and potentially on the plastic digestion vessel. Part or all of the oxidized uranium is dissolved during the subsequent uranium metal dissolution step with $10 \mathrm{M} \mathrm{HNO}_{3}$ where it adds to the uranium reporting to the solution as dissolved metal. The net effect of this tramp residual uranium is that it will be interpreted as uranium metal being present in the sludge even for sludge samples containing no uranium metal. Based on the tests performed to-date with actual sludge, this residual uranium is equivalent to a uranium metal background of about $0.004 \mathrm{wt} \%$. Thus, the 
selective-dissolution method will always predict the presence of a small threshold quantity of uranium metal. ${ }^{(a)}$

- Testing with actual sludge performed at the low end of the expected range of uranium metal concentration in the sludge ( 0.007 to $0.015 \mathrm{wt} \%$, settled sludge basis) achieved uranium metal recoveries ranging from 106 to $179 \%$.

- Testing at higher uranium metal levels (0.025 to $1.29 \mathrm{wt} \%$, settled sludge basis), encompassing the design basis KE Floor sludge concentration of $0.26 \mathrm{wt} \%$, achieved $99.4 \mathrm{wt} \%$ recovery with $3.3 \%$ uncertainty at one standard deviation.

(a) It is noted that all chemical or radiochemical analyses have a lower analytical limit that, if reached for any sample, constitutes an estimate of the highest potential concentration of the analyte in question. 


\subsection{References}

Alford MD. 1957. I. and E. Fuel Element Dissolution Rate Studies. HW-52808, Hanford Atomic Products Operation, Richland, WA.

Blaine HT. 1960. Dissolution of Power Reactor Fuel Cores. HW-66320, Hanford Atomic Products Operation, Richland, WA.

Blanco RE, and CD Watson. 1961. "Head-End Processes for Solid Fuels." In: Reactor Handbook, $2^{\text {nd }}$ Edition, Vol. II, "Fuel Reprocessing." SM Stoller and RB Richards, editors. Interscience Publishers, Inc., New York, NY, pp. 60-64.

Bredt PR, CH Delegard, AJ Schmidt, and KL Silvers. 1999. Testing and Analysis of Consolidated Sludge Samples from the 105 K East Basin Floor and Canisters. PNNL-13341, Pacific Northwest National Laboratory, Richland, WA.

Brosheer JC, FE Lenfesty, and JF Anderson, Jr. 1954. "Solubility in the System Aluminum Phosphate Phosphoric Acid - Water." Journal of the American Chemical Society 76:5951-5956.

Bryan SA, CH Delegard, AJ Schmidt, RL Sell, and KL Silvers, SR Gano, and BM Thornton. 2004. Gas Generation from K East Basin Sludges - Series II Testing. PNNL-13446, Rev. 1, Pacific Northwest National Laboratory, Richland, WA.

Colvin, CA. 1959. Partially Dissolved Fuel Slugs from REDOX Dissolvers. HW-58561, Hanford Atomic Products Operation, Richland, WA.

Delegard CH, and DE Rinehart. 1998. Radionuclide Leaching from Organic Ion Exchange Resin. PNNL-12105, Pacific Northwest National Laboratory, Richland, WA.

Delegard CH, DE Rinehart, and FV Hoopes. 1998. Distribution of Components in Ion Exchange Materials Taken from the K East Basin and Leaching of Ion Exchange Materials by Nitric/Hydrofluoric Acid and Nitric/Oxalic Acid. PNNL-12111, Pacific Northwest National Laboratory, Richland, WA.

Delegard CH, SA Bryan, AJ Schmidt, PR Bredt, CM King, RL Sell, LL Burger, and KL Silvers. 2000. Gas Generation from K East Basin Sludges - Series I Testing. PNNL-13320, Pacific Northwest National Laboratory, Richland, WA.

Delegard CH, AJ Schmidt, RL Sell, SI Sinkov, SA Bryan, SR Gano, and BM Thornton. 2004. Final Report - Gas Generation Testing of Uranium Metal in Simulated K Basin Sludge and in Grouted Sludge Waste Forms. PNNL-14811, Pacific Northwest National Laboratory, Richland, WA.

DOE (see U.S. Department of Energy) 
Evans TF. 1956. Pilot Plant Dissolution of Unjacketed Fuel Elements. HW-46093, Hanford Atomic Products Operation, Richland, WA.

Evans TF. 1958. Continuous Pilot Plant Dissolution of Aluminum-Jacketed Uranium Fuel Elements in Nitric Acid. HW-56403, Hanford Atomic Products Operation, Richland, WA.

Gresky AT. 1952. Recovery of Nitrogen Oxides and Rare Gas Fission Products from the Dissolution of Irradiated Uranium. ORNL-1208, Oak Ridge National Laboratory, Oak Ridge, TN.

Hoddeland JE, and TW Boyer. 1947. The Dissolution of X Metal in Nitric Acid. CRX-318.

Hyde AC, CH Holt, G Bird, SG Thompson, and JL Dreher. 1944. Process Development and Chicago Semi-Works Operation. CN-1751, University of Chicago, Chicago, IL.

Iler RK. 1979. The Chemistry of Silica, John Wiley \& Sons, New York, NY.

Kanno T, and H Mimura. 1985. "Ion-Exchange Properties of Zeolites and Their Application to Processing of High-Level Liquid Waste." Inorganic Ion Exchangers and Adsorbents for Chemical Processing in the Nuclear Fuel Cycle. IAEA-TECDOC-337, International Atomic Energy Agency, Vienna, Austria.

Lacher JR, JD Saltzman, and JD Park. 1961. “Dissolving Uranium in Nitric Acid.” Industrial and Engineering Chemistry 53(4):282-284.

Makenas BJ, TL Welsh, RB Baker, DR Hansen, and GR Golcar. 1996. Analysis of Sludge from Hanford K East Basin Floor and Weasel Pit. WHC-SP-1182, Rev. 0, Westinghouse Hanford Company, Richland, WA.

Marsh, SF, ZV Svitra, and SM Bowen. 1994. Distributions of 14 Elements on 63 Absorbers from Three Simulant Solutions (Acid-Dissolved Sludge, Acidified Supernate, and Alkaline Supernate) for Hanford HLW Tank 102-SY. LA-12654, Rev., Los Alamos National Laboratory, Los Alamos, NM.

Moore RL, WW Schulz, and SJ Walter. 1953. Phosphate Catalysis in Nitric Acid Dissolutions of Uranium Metal. HW-28995, Hanford Atomic Products Operation, Richland, WA.

Moore RL, and RA Watts, Jr. 1954. "Uranium Dissolution Studies.” pp. 14-14a in Quarterly Progress Report - Chemistry Unit - January, February, March, 1954. HW-31630, AH Bushey, Hanford Atomic Products Operation, Richland, WA.

QAPjP. 2007. Hydrothermal Treatment of K Basin Sludge Quality Assurance Project Plan. 53451QAPjP, Rev. 0, May 2007, Pacific Northwest National Laboratory, Richland, WA.

Reddy RG, and Z Cai. 1996. "Removal of Radionuclides Using Zeolites.” Light Metals 1996. W Hale, editor, The Minerals, Metals \& Materials Society, Warrendale, PA. 
Schmidt AJ. 2006. Spent Nuclear Fuel Project Databook, Volume 2, Sludge. HNF-SD-SNF-TI-015, Rev. 13A, Fluor Hanford, Inc., Richland, WA.

Schmidt AJ and CH Delegard. 2003. Updated Volumetric Expansion Factors for K Basin Sludge During Storage. PNNL-14228, Pacific Northwest National Laboratory, Richland, WA.

Schmidt AJ, CH Delegard, KL Silvers, PR Bredt, CD Carlson, EW Hoppe, JC Hayes, DE Rinehart, SR Gano, and BM Thornton. 1999. Validation Testing of the Nitric Acid Dissolution Step within the K Basin Sludge Pretreatment Option. PNNL-12120, Pacific Northwest National Laboratory, Richland, WA.

Schmidt AJ, RT Hallen, DS Muzatko, and SR Gano, 2004. KE Basin Sludge Flocculant Testing. PNNL-14730, Pacific Northwest National Laboratory, Richland, WA.

Silvers KL, JJ Wagner, and RT Steele. 2000. TCLP Preparation and Analysis of K East Basin Composite Sludge Samples. PNNL-13280, Pacific Northwest National Laboratory, Richland, WA.

Sinkov SI, CH Delegard, and AJ Schmidt. 2008. Preparation and Characterization of Uranium Oxides in Support of the K Basin Sludge Treatment Project. PNNL-17678, Pacific Northwest National Laboratory, Richland, WA.

Swanson J. 1988. Recent Studies Related to Head-End Fuel Processing at the Hanford PUREX Plant. PNL-6609, Pacific Northwest Laboratory, Richland, WA.

Swanson JL, LA Bray, HE Kjarmo, JL Ryan, CL Matsuzaki, SG Pitman, and JH Haberman. 1985. Laboratory Studies of Shear/Leach Processing of Zircaloy Clad Metallic Uranium Reactor Fuel. PNL-5708, Pacific Northwest Laboratory, Richland, WA.

Thamer BJ, RM Bidwell, HM Busey, RA Clark, SH Cox, LA Geoffrion, RP Hammond, GE Meadows, BJ Melton, RH Perkins, JR Phillips, MG Redman, JD Rogers, A Sesonske, LR Sitney, EO Swickard, WR Wykoff, and JB Zorn. 1956. The Properties of Phosphoric Acid Solutions of Uranium as Fuels for Homogeneous Reactors. LA-2043, Los Alamos Scientific Laboratory, Los Alamos, NM (http://libwww.lanl.gov/cgi-bin/getfile?00320782.pdf).

U.S. Department of Energy (DOE). 2007. Hanford Analytical Services Quality Assurance Requirements Documents. DOE/RL-96-68, U.S. Department of Energy, Richland, WA.

Weigel F, JJ Katz, and GT Seaborg. 1986. Figure 7.18 in Plutonium, chapter 7 in The Chemistry of the Actinide Elements, $2^{\text {nd }}$ edition, JJ Katz, GT Seaborg, and LR Morss, editors, Chapman and Hall, London, UK. 